\title{
Patenting Speech
}

\author{
Dan L. Burk*
}

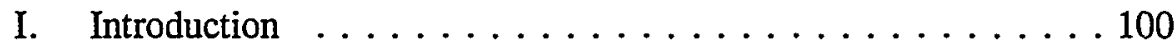

II. Software as Speech . . . . . . . . . . . . . . . 102

A. Expression in Software . . . . . . . . . . . . 105

B. Expression as Communication . . . . . . . . . . . 109

C. Expression and Function .............. 116

III. Software and Copyright $\ldots \ldots \ldots \ldots \ldots \ldots \ldots \ldots \ldots \ldots$

A. Copyright and Speech . . . . . . . . . . . . 124

B. Copyright and Communication . . . . . . . . . 126

C. Copyright and Function . . . . . . . . . . 130

IV. Software and Patent . . . . . . . . . . . 135

A. Patents and Function . . . . . . . . . . 136

1. Mental Steps . . . . . . . . . . . . . . 137

2. Printed Matter .................... 141

B. Patents and Expression . . . . . . . . . . 145

C. Patents and Speech ............... 150

1. The Function of Fair Use . . . . . . . . . 151

2. Experimental Use ................. . 154

3. Compulsory Licensing . . . . . . . . . . 158

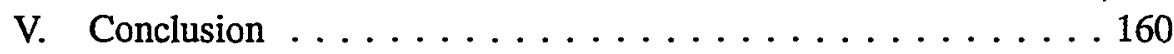

* Professor of Law, University of Minnesota. A previous version of this Article was presented at the 27th Annual Telecommunication Research and Policy Conference in Alexandria, Virginia. I would like to thank the organizers of the Conference, particularly Julie Cohen, for helping me to develop some of the ideas presented here. This Article benefitted from generous research support underwritten by the University of Minnesota Law School; from helpful comments offered by Professors Mark Lemley, Larry Lessig, Pamela Samuelson, Dan Farber, David McGowan, Dan Gifford, and Ann Burkhart; and from capable research assistance supplied by Ms. Arlene Forrest. 


\section{Introduction}

The adoption of novel expressive technology has long been attended by the maxim, now almost a platitude, that every new medium of expression presents its own peculiar problems of regulation. ${ }^{1}$ In the past, this adage has signified that the permissible limits of governmental regulation of speech in motion picture, ${ }^{2}$ broadcast, ${ }^{3}$ cable, ${ }^{4}$ or even Internet network ${ }^{5}$ media might vary with the characteristics of the technology. But in an era of rapidly evolving technology, the more serious questions regarding freedom of expression in new media may lie not in the danger of direct governmental regulation, but rather in governmental grants of ownership over the information expressed via such media. The threat of private, albeit state-sponsored, suppression of speech is rising to new prominence in part because the new media of expression are presenting peculiar and even unprecedented problems of intellectual property classification. In particular, new technologies have begun to transcend the traditional division between ownership regimes in copyright, which have been adapted to accommodate the public interest in expressive media, and the ownership regimes in patent, which offer no such accommodation of expression.

This convergence of patents and copyrights comes as no surprise to those who specialize in the area. Intellectual property scholars have for some time recognized the emergence of legal "hybrid" technologies that are eroding the distinctions between patent and copyright protection because these technologies fit into neither traditional regime. ${ }^{6}$ Foremost among these hybrids is computer software, which has significantly altered-some might say warped - both patent and copyright law in order to fit within their protection. ${ }^{7}$ Much of the stretching that has occurred in these areas has been an attempt to accommodate software as a technology that seems expressive, yet also functional. But the implications of

1. Southeastern Promotions, Ltd. v. Conrad, 420 U.S. 546, 557 (1975) ("Each medium of expression, of course, must be assessed for First Amendment purposes by standards suited to it, for each may present its own problems.").

2. Joseph Burstyn, Inc. v. Wilson, 343 U.S. 495, 502 (1952).

3. FCC v. Pacifica Found., 438 U.S. 726, 748 (1978).

4. Denver Area Educ. Telecomm. Consortium v. FCC, 518 U.S. 727, 741-42 (1996).

5. Reno v. ACLU, 521 U.S. 844, 868-69 (1997).

6. See generally Rochelle Cooper Dreyfuss, $A$ Wiseguy's Approach to Information Products: Muscling Copyright and Patent Into a Unitary Theory of Intellectual Property, 1992 SUP. CT. REv. 195, 221-33; Dennis S. Karjala, The Relative Roles of Patent and Copyright in the Protection of Computer Programs, 17 J. MARSHALL J. COMPUTER \& INFO. L. 41 (1998); J.H. Reichman, Charting the Collapse of the Patent-Copyright Dichotomy: Premises for a Restructured International Intellectual Property System, 13 CARDOZO ARTS \& ENT. L.J. 475 (1995).

7. Professor Reichman has suggested that biotechnology in particular may be another. See J.H. Reichman, Legal Hybrids Between the Patent and Copyright Paradigms, 94 COLUM. L. REv. 2432, 2454 (1994). 
software's dual nature are not confined to the realm of intellectual property, and it may be that the legal hybrid effect could extend into other areas of law.

Indeed, it may have already done so. In this Article, I address the implications of a series of recent court decisions regarding the expressive nature of computer software; in particular, I discuss the implications of the decisions in Bernstein v. United States ${ }^{8}$ and Junger v. Daley ${ }^{9}$ holding that software is protected speech under the First Amendment. These cases considering software as speech revolve primarily around governmental regulations restricting the dissemination of cryptographic software. In some cases, the restrictions at issue were administrative regulations designed to prevent the export of software intended to encode messages; more recently, the restrictions at issue were provisions of the Digital Millennium Copyright Act ("DMCA") designed to prevent circulation of software intended to decode copyrighted works. ${ }^{10}$ In both Bernstein and Junger, the promulgators of the software at issue claimed that their computer code is protected expression under the First Amendment.

I should perhaps categorically state at the outset that I have little patience for either set of software restrictions, believing both to be counterproductive and ultimately futile. ${ }^{11}$ As a consequence, I am delighted with the outcome of the trial and appellate decisions in Bernstein striking down the Clinton Administration's disingenuous software export policy, and I am equally dismayed by a recent trial court opinion upholding one of the most ill-considered provisions of the DMCA. ${ }^{12}$ But I am more than a little disturbed by the route that was taken in reaching the Bernstein result and would be equally disturbed if such reasoning were adopted in order to curb the excesses of DMCA copyright protectionism. In either

8. 176 F.3d 1132 (9th Cir. 1999).

9. 209 F.3d 481 (6th Cir. 2000).

10. See 17 U.S.C. § 1201(a)(2) (Supp. IV 1998).

11. For an overview of cryptography issues, and a simplified explanation of public key cryptography, see David Friedman, $A$ World of Strong Privacy: Promises \& Perils of Encryption, Soc. PHIL. \& PoL'Y, Summer 1996, at 212. For a more detailed discussion of U.S. encryption policy, see A. Michael Froomkin, It Came From Planet Clipper: The Battle Over Cryptographic Key "Escrow," 1996 U. Chl. Legal F. 15 [hereinafter Froomkin, It Came From Planet Clipper]; A. Michael Froomkin, The Metaphor is the Kcy: Cryptography, The Clipper Chip, and the Constitution, $143 \mathrm{U}$. PA. L. REV. 709 (1995) [hereinafter Froomkin, The Metaphor is the Key].

For trenchant criticism of the anticircumvention provisions of the Digital Millennium Copyright Act, see Pamela Samuelson, Intellectual Property and the Digital Economy: Why the Anti-Circumvention Regulations Need to Be Revised, 14 BERKELEY TECH. L.J. 519, $534-46$ (1999); see also Julie E. Cohen, Some Reflections on Copyright Management Systems and Laws Designed to Protect Them, 12 BERKELEY TECH. L.J. 161, 172-75 (1997) (criticizing the anticircumvention provisions in the DMCA's predecessor, the National Information Infrastructure Copyright Protection Act).

12. See generally Universal City Studios, Inc. v. Reimerdes, 111 F. Supp. $2 d 294$ (S.D.N.Y. 2000). 
case, I believe the long-term implications of holding software to be protected speech could be more troublesome than the immediate folly such a holding might rectify.

I do not intend in this Article to undertake a comprehensive discussion of the relationship between software and speech. Such a formidable analytical undertaking far exceeds the limits of this Article; in any event, there are likely others better equipped than I to attempt the difficult task of defining the relationship of the First Amendment to computer code. My agenda here is far more modest and primarily negative in its objective: I intend only to address the intellectual property implications of these cases by bringing to bear the jurisprudence of over twenty years' application of intellectual property law to software and by explicating what I believe to be some extrennely undesirable ramifications of the Bernstein approach to patent law. Among these ramifications, I suggest, is the imminent collapse of the carefully drawn constitutional balance between the Intellectual Property Clause and the Free Speech Clause. Of course, this argument itself has implications for First Amendment jurisprudence, as well as for intellectual property law. Thus, because the dimensions of the categorical problem are an important part of the intellectual property problem, I shall begin by sketching the outline of the First Amendment speech issue. I then turn to the parallel, recognized by the trial court in Bernstein, between expression for purposes of copyright and expression for purposes of the First Amendment. Finally, I shall discuss how lessons learned from applying copyright law to computer code might be applied toward what seems to be the inevitable application of patent law to software as "speech." I conclude with some observations about future developments in both the jurisprudence of patent and of the First Amendment.

\section{Software as Speech}

If computer software is to be a candidate for First Amendment protection, then any state restriction on the use or distribution of computer code raises the issue of whether software qualifies as speech. Given the versatility of computer software applications, restrictions could arise in a wide variety of situations. For example, in United States v. Mendlesohn ${ }^{13}$ distributors of bookmaking software contested their criminal conviction for interstate transport of wagering paraphernalia on the grounds that their program constituted speech protected by the First Amendment. ${ }^{14}$ More recently, hackers and Internet web site owners, faced with a private suit under the Digital Millennium Copyright Act, raised sinilar First

13. 896 F.2d 1183 (9th Cir. 1990).

14. Id. at 1185-86. 
Amendment claims with regard to a decryption program for Digital Versatile Disc ("DVD") playback. ${ }^{15}$ The program, called DeCSS, was designed to permit access to files controlled by the Content Scramble System (CSS), a form of encryption access control that limits DVD playback to certain computer operating. systems and stand-alone DVD players. ${ }^{16}$ The developers of DeCSS allege that their intent was to allow DVDs to be played on the open-source Linux operating systems. ${ }^{17}$ However, the program runs afoul of the access control anticircumvention provisions of the Copyright Act, which prohibit persons from manufacturing, importing, or providing to the public "any technology, service, device, component, or part thereof" designed primarily to circumvent technological controls on copyrighted works. ${ }^{18}$

Beyond these examples, the majority of court opinions addressing the expressive status of computer software have arisen out of challenges to the export regulation of technologies that enable strong encryption of computer communications. The International Traffic in Arms Regulations ("ITAR") 19 under the Arms Export Control Act ("AECA") ${ }^{20}$ administered by the Department of State, and the Export Administration Regulations ("EAR") 21 under the International Emergency Economic Powers Act ("IEEPA") $)^{22}$ administered by the Department of Commerce restrict the export or transfer outside the United States of controlled technologies, including software, by requiring a license in order to export them. Licensing is accomplished by submitting the potential exports to the appropriate agency for "commodity classification" review. ${ }^{23}$ Export licenses may be denied or indefinitely delayed for software whose availability could seriously inupede the eavesdropping capability of U.S. military and law enforcement agencies. ${ }^{24}$

15. Reimerdes, 111 F. Supp. $2 \mathrm{~d}$ at 330.

16. Id. at 304; see also Andy Patrizio, Why the DVD Hack Was a Cinch, WIRED NEWS, at http://www.wired.com/news/technology/0,1282,32263,00.html(Nov.2, 1999)(explainingthat “DeCSS is a tiny $(60 \mathrm{~KB})$ utility that copies the encrypted DVD video file . . . and saves it to the hard disk without encryption").

17. Id. at 311; see also Lynn Burke, DVD Case: It's A Linux Thing, WIRED NEwS, at http://www.wired.com/news/politics/0,1283,33925.00.html (Jan. 28, 2000).

18. 17 U.S.C. $\$ 1201(a)(2)(A)$ (Supp. IV 1998).

19. 22 C.F.R. $\S \S 120-130$ (1999).

20. 22 U.S.C. $\S \S 2751-2799 a a-2$ (1994).

21. 15 C.F.R. pts. 730-774 (2000). Jurisdiction over nonmilitary encryption exports was transferred from the State Department (under the ITAR) to the Commerce Department Bureau of Export Administration ("BXA") (under the EAR) by executive order on November 15, 1996. See Exec. Order No. 13,026, 3 C.F.R. 228 (1996), reprinted in 50 U.S.C. app. § 2403 (Supp. IV 1998).

22. 50 U.S.C. \$§ 1701-1706 (1994 \& Supp. IV 1997). The EAR export control system was originally promulgated under the Export Administration Act of 1979 ("EAA"), 50 U.S.C.A. §§ 24012420. When the EAA lapsed on August 24, 1994, the President extended the system under IEEPA.

23. 15 C.F.R. pt. 742 , Supp. 6 (2000).

24. The December 1998 Wassenaar Arrangement (between thirty-three countries with common controls on exports, including encryption) made a number of changes to modernize encryption controls. 
This system of review and licensing was originally designed to keep munitions technology out of the hands of the Soviet Union, ${ }^{25}$ but since the end of the Cold War the system is now (supposedly) employed to keep the technology out of the hands of terrorists, drug lords, child pornographers, and other targets of law enforcement investigation. ${ }^{26}$ While it is unclear that the restrictions have done anything at all to impede the activities of the purported targets, ${ }^{27}$ it is quite clear that the restrictions are onerous to U.S. software publishers, ${ }^{28}$ obnoxious to computer researchers, ${ }^{29}$ and odious to civil libertarians. ${ }^{30}$ Robust encryption technology is central to a wide variety of commercial and private Internet activities, including the security, authentication, and validation of electronic transactions. ${ }^{31}$ It also offers citizens a technological means to secure the rights of private and anonymous speech. ${ }^{32}$ Indeed, some commentators have observed that the choice to communicate in encrypted text is much like the choice to speak in an obscure language. They suggest that the governmental policy on encryption has therefore served to burden-perhaps unconstitutionally burden-such speech because it is impossible to speak in this manner without access to encryption technology. ${ }^{33}$

See Revisions to Encryption Items; Interim Final Rule, 65 Fed. Reg. 2492 (2000) (to be codified at 15 C.F.R. pts. 734, 740, 742, 770, 772, and 774) (adopting the changes required by the Wassenar Arrangement). The new regulations update and simplify export controls on encryption products by. providing "a one-time technical review of encryption products in advance of sale, a streamlined postexport reporting system, and a process that permits the government to review the exports of strong encryption to foreign government and military organizations and to nations of concert.." Press Release, Statement by the Press Secretary, Administration Announces New Approach to Encryption, available at http://www.pub.whitehouse.gov/WH/Publications/htm//Publications.html (Sept. 16, 1999).

25. See John F. McKenzie, Implementation of the Core List of Export Controls: Computer and Software Controls, 5 SOFTWARE L.J. 1, 1 (1992).

26. See Froomkin, The Metaphor is the Key, supra note 11, at 743-46.

27. See id. at 744-46.

28. See Charles L. Evans, U.S. Export Control of Encryption Software: Efforts to Protect National Security Threaten the U.S. Software Industry's Ability to Compete in Foreign Markets, 19 N.C. J. INT'L L. \& COM. REG. 469, 489 (1994) (discussing executives' fears that American export controls on encryption software will force companies to lose market share, revenue, and jobs).

29. See infra text accompanying notes 80-81.

30. As libertarian professor David Friedman observes,

This [export] policy makes little sense as a way of keeping foreign governments from learning how to protect their secrets and steal ours, since it does not prevent the domestic sale of such [encryption] products ... . . It makes more sense as a way of slowing the spread of encryption into general use.

Friedman, supra note 11, at 224.

31. See A. Michael Froomkin, The Essential Role of Trusted Third Parties in Electronic Commerce, 75 OR. L. REV. 49, 68-69 (1996); A. Michael Froomkin, Flood Control on the Information Ocean: Living with Anonymity, Digital Cash, and Distributed Databases, 15 J.L. \& CoM. 395 (1996).

32. See Froomkin, The Metaphor is the Key, supra note 11; Friedman, supra note 11, at 212-18.

33. See, e.g., Froomkin, The Metaphor is the Key, supra note 11 at 865-67 (" [A] cipher resembles a foreign language .... If one accepts the analogy, it follows that no cryptosystems may be outlawed."); Lee Tien, Publishing Software as a Speech Act, 15 BERKELEY TECH. L.J. 629, 682-83 (2000); $c f$. Yu Cong Eng v. Trinidad, 271 U.S. 500 (1926) (invalidating a law that prohibited the maintenance of accounting books in any language other than English or Spanish); Meyer v. Nebraska, 
But the challenge to such regulations has been couched not so much as an assertion that cryptographic software is a necessary mechanism to facilitate encrypted or anonymous speech, but rather as the assertion that cryptographic software is speech itself. ${ }^{34}$ Similarly, although the DeCSS software might be characterized as a means to facilitate protected speech, such as the fair use of lawfully purchased DVDs, the more challenging argument against its suppression may hinge on whether it constitutes a "device" under the anticircumvention provisions of the Copyright Act or whether the software itself constitutes protected speech. Determining the viability of this direct challenge to software restrictions entails the formidable task of separating expression from function under the First Amendment.

\section{A. Expression in Software}

Sorting out whether software constitutes a device or a form of speech has meant grappling with the definition of what constitutes speech and whether a text that is part of a machine falls within that definition. Computer programs are typically written in symbolic notation that appears to be a kind of text, and yet that text also performs functions within a machine. Courts and the litigants before them have struggled to find analogies to help characterize this odd subject matter, and often the analogies point in different directions, highlighting either the expressive or the functional nature of software. Perhaps the most striking form of this dilemma has been manifested in the confusion over governmental regulation of computer code in different formats, resulting in different treatment for symbols printed in hard copy and symbols saved to machine-readable niedia.

For example, in Karn v. United States Department of State, ${ }^{35}$ the plaintiff sought to export the book Applied Cryptography, which contained within its pages the printed code of numerous cryptographic programs. ${ }^{36}$ The book was also accompanied by a computer disk that contained machine-readable versions of the same code. ${ }^{37}$ The plaintiff submitted both items to the Department of State for commodity jurisdiction

262 U.S. 390 (1923) (holding a law prohibiting school instruction in German rather than English unconstitutional); Yniguez v. Arizonans for Official English, 69 F.3d 920 (9th Cir. 1995), vacated on other grounds, 520 U.S. 43 (1997) (invalidating a law declaring English the "official language" of Arizona); Asian-Am. Bus. Group v. City of Pomona, 716 F. Supp. 1328 (C.D. Cal. 1989) (invalidating a law restricting the use of non-English alphabetical characters).

34. See Junger v. Daley, 209 F.3d 481, 484 (6th Cir. 2000); Bernstein v. United States Dep't of Justice, 176 F.3d 1132, 1136 (9th Cir. 1999).

35. 925 F. Supp. 1 (D.D.C. 1996).

36. Id. at 3 .

37. Id. at 3-4. 
classification and was informed that the book could be exported but the disk could not. ${ }^{38}$ A similar problem faced the plaintiff in Junger $v$. Daley, ${ }^{39}$ where a computer law professor at Case Western Reserve University School of Law wished to place class materials including encryption software source code on his course web site. ${ }^{40}$ Because placement of the materials on the Internet would constitute an export of the source code, Junger submitted the materials for commodity classification review. ${ }^{41}$ As in Karn, the Commerce Department found that a printed chapter of Junger's book, entitled Computers and the Law, containing source code was not restricted, but that the export of the software itself would require a license. ${ }^{42}$ And again, in Bernstein v. United States Department of State, ${ }^{43}$ the plaintiff, an academic mathematics and computer researcher, submitted his encryption algorithm "Snuffle" to the State Department to determine whether it fell under the ITAR restrictions. ${ }^{44}$ Along with the source code for a program implementing the algorithm, he also submitted an academic paper and written description of the encryption system. ${ }^{45}$ Initially, Bernstein was denied permission to export or present his academic paper or the computer code outside the United States. ${ }^{46}$ This ruling was subsequently rescinded after he filed suit, and the government instead asserted, much as in Karn, that the export restriction only applied to the source code itself, not to the printed or English descriptions of the code: ${ }^{47}$

The uncertain nature of software has also been reflected in the arguments used to characterize it as either expressive or functional. Those challenging governmental restrictions have tended to describe software as expressive, emphasizing its textual nature and capacity for conveying programming ideas to the community of programmers. ${ }^{48}$ For instance, in each of the cryptography cases, the plaintiffs argued that computer source code, even though incomprehensible to the majority of people, is comprehensible to other programmers who are trained to read it, and such individuals can extract from the code ideas about the nature and function

38. Id.

39. 8 F. Supp. $2 d 708$ (N.D. Ohio 1998).

40. Id. at 713-14.

41. Id. at 714 .

42. Id.

43. n922 F. Supp. 1426 (N.D. Cal. 1996).

44. Id. at 1430 .

45. Id.

46. Id.

47. Id.

48. See Jungerv. Daley, 209 F.3d 481, 484-85 (6th Cir. 2000); Bernstein v. United States Dep't of Justice, 176 F.3d 1132, 1139-43 (9th Cir. 1999). 
of the software. ${ }^{49}$ Some courts have accepted this argument. In the Sixth Circuit Junger opinion, ${ }^{50}$ the panel accepted this argument, comparing program source code to musical notation that, although incomprehensible to the majority of people, communicates to other musicians. ${ }^{51}$ In Bernstein, the trial court similarly found that source code is protected speech written in "a complex system of understood meanings within specific communities." 52 The opinion eniphasizes that source code "is written, albeit in computer language rather than in English," but the court found "no meaningful difference between computer language, particularly highlevel computer languages . . . and German or French."53 This hold-img was affirmed on appeal by a divided panel of the Court of Appeals for the Ninth Circuit. ${ }^{54}$ The panel majority, like the trial court, stressed that source code is "meant to be read and understood by humans and that it can be used to express an idea or a method." 55

Other courts considering the matter have reached their conclusions without deciding whether software is speech, demonstrating a caution about accepting software as a form of expression. In Karn and in the DVD case, Universal City Studios, Inc. v. Reimerdes, ${ }^{56}$ the courts both assumed for the sake of analysis-but did not decide-that First Amendment protection could extend to computer source code. ${ }^{57}$ Each court then went on to hold that restrictions of the code, under either the ITAR export controls or the DMCA, respectively, were constitutionally permissible. The Karn opinion concludes that the nature of the software is immaterial because the governmental restrictions were directed to the functional impact of machine-readable software, not toward regulating any expressive content. $^{58}$ Thus, the court concluded that the regulatory scheme was "content-neutral." ${ }^{59}$ Applying the O'Brien test for symbolic speech, ${ }^{60}$.

49. Karn v. United States Dep't of State, 925 F. Supp. 1, 9 (D.D.C. 1996); Bernstein, 922 F. Supp. at 1434-35.

50. Junger v. Daley, 209 F.3d 481 (6th Cir. 2000).

51. Id. at 484 .

52. Bernstein, 922 F. Supp. at 1435.

53. Id. at 1434-35.

54. Bernstein v. United States Dep't of Justice, 176 F.3d 1132 (9th Cir. 1999).

55. Id. at 1140 .

56. 111 F. Supp. 2d 294 (S.D.N.Y. 2000).

57. Id. at 327; Kam v. United States Dep't of State, 925 F. Supp. 1, 9-10 (D.D.C. 1996).

58. Karn, 925 F. Supp. at 10-11.

59. Id. at 11 .

60. The O'Brien test was laid out by Chief Justice Warren as follows:

[A] govemmental regulation is sufficiently justified if it is within the constitutional power of the Government; if it furthers an important or substantial governmental interest; if the govemmental interest is unrelated to the suppression of free expression; and if the incidental restriction on First Amendment freedoms is no greater than is essential to the furtherance of the interest.

United States v. O'Brien, 391 U.S. 367, 377 (1968). 
the court found that preventing the spread of cryptographic software furthered a significant governmental interest in national security and that the regulation was not substantially broader than necessary to further that interest. ${ }^{61}$ Similarly, the opinion in Reimerdes reasoned that the DMCA restriction on cryptographic "hacking" tools was permissible because the law is directed toward the protection of copyrighted intellectual property, not toward the suppression of the tools' expressive content, if any. ${ }^{62}$

Other courts have been less consequentialist, directly taking on the question of whether software is expressive or functional and finding it to be primarily functional. Both the Mendelsohn appellate court and the Junger trial court admit that some software might be expressive, but held that the particular software at issue was intended to perform a particular function, not to communicate ideas. ${ }^{63}$ In particular, the Junger trial court rejected as "unsound" the reasoning of the Bernstein trial court that "language equals protected speech." 64 The Junger trial court found the export restrictions constitutional because "encryption source code is inherently functional" and "because the Export Regulations are not directed at source code's expressive elements." 65 Noting that source code is a series of instructions to a computer, the court concedcd that some software might be expressive, but that encryption source code is used to enable a computer to carry out a certain task, rather than to communicate ideas. ${ }^{66}$ Even though source code may have communicative elements, the court held that this does not necessarily trigger First Amendment protection; rather, because source code is designed to be functional, it is insufficiently communicative for its regulation to pose a real and substantial threat to free speech. The trial court therefore applied intermediate scrutiny to the challenged regulation and held that the export restrictions are constitutionally permissible. ${ }^{67}$

In contrast, the appellate panels that have most recently addressed the issue have found the software expression glass half full rather than half enipty. The Sixth Circuit panel in Junger reasoned that although software has functional and expressive aspects, the latter characteristic entitles it to constitutional protection. ${ }^{68}$ The Ninth Circuit panel majority in Bernstein

61. Karn, 925 F. Supp, at 11-12.

62. Reimerdes, 111 F. Supp. at 329.

63. United States v. Mendelsohn, 896 F.2d 1183, 1186 (9th Cir. 1990); Junger v. Daley, 8 F. Supp. 2d 708, 716 (N.D. Ohio 1998).

64. Junger, 8 F. Supp. 2d at 712, 716 (citing Bernstein v. United States Dep't of State, 922 F. Supp. 1426, 1434 (N.D. Cal. 1996)).

65. Id.

66. Id. at 722 .

67. Id. at 722-23.

68. Junger v. Daley, 209 F.3d 481, 484-85 (6th Cir. 2000). 
went farther; the panel dismissed the functional nature of the code as essentially irrelevant, stating that it rejected the notion that "functionality necessarily puts expression beyond the protections of the Constitution."69 The Bernstein trial opinion was yet more effusive on this point, rejecting the functionality of the code as immaterial because recipes and do-ityourself manuals are protected by the First Amendment even though they are also functional. ${ }^{70}$ Comparing software to music encoded in a player piano roll, the court held software "no less protected for being wholly functional."71 Expanding on this analogy, the court further noted that under the Copyright Act, computer programs are defined as "instructions" used directly or indirectly to cause a certain result in a machine and that copyright protects the expressive content of such instructions. ${ }^{72}$ Thus, the Bernstein trial court opinion embraces the argument, first raised by the defendants but rejected by the appellate court in Mendelsohn, ${ }^{73}$ that the copyrightable status of software signals that software has an expressive content that must qualify for First Amendment protection.

\section{B. Expression as Communication}

In each of these decisions the gravamen of the arguments raised concerns about whether or not software deserves the highest level of First Amendment protection, or in other words, whether software is protected speech. The question of what constitutes speech is not new to First Amendment jurisprudence. The Supreme Court has previously considered whether nude dancing, ${ }^{74}$ flag burning, ${ }^{75}$ and parade marching ${ }^{76}$ constitute speech for First Amendment purposes. The Supreme Court at times has based its definition of speech upon whether the activity is "communicative" or whether it conveys a message to an audience. ${ }^{77}$ Yet

69. Bernstein v. United States Dep't of Justice, 176 F.3d 1132, 1142 (9th Cir. 1999).

70. Bernstein v. United States Dep't of State, 922 F. Supp. 1426, 1435 (N.D. Cal. 1996).

71. Id.

72. Id. at 1436; see also 17 U.S.C. § 101 (1994) (defining "computer program").

73. United States v. Mendelsohn, 896 F.2d 1183, 1185 (9th Cir. 1990).

74. City of Erie v. Pap's A.M., 120 S.Ct. 1382 (2000); Barnes v. Glen Theatre, Inc., 501 U.S. 560 (1991); Schad v. Borough of Mount Ephraim, 452 U.S. 61 (1981).

75. United States v. Eichman, 496 U.S. 310 (1990); Texas v. Johnson, 491 U.S. 397 (1989).

76. Hurley v. Irish-Am. Gay, Lesbian and Bisexual Group of Boston, Inc., 515 U.S. 557 (1995).

77. See Hill v. Colorado, 120 S.Ct. 2480,2492 (2000) (holding that it may be necessary to review the content of speech in order to distinguish "innocuous speech" from the "expressive activities" of picketing and demonstrating); Meyer v. Grant, 486 U.S. 414, 421-22 (1988) (" $[T]$ he circulation of a petition involves the type of interactive communication concerning political change that is appropriately described as "core political speech.'"); Spence v. Washington, 418 U.S. 405, 409-10 (1974) (holding that a flag displayed upside down bearing a peace symbol possessed "[a]n intent to convey a particularized message" and that "in the surrounding circumstances the likelihood was great that the message would be understood by those who viewed it"); Tinker v. Des Moines Indep. Cmty. Sch. 
conveying a message cannot by itself form the touchstone for First Amendment protection because a majority of people cannot perceive a message in many types of expression-say, modern art or Navajo tribal chants. ${ }^{78}$ Yet, we would be reluctant to place such expressive activity outside the category of protected speech, even if it is understood by few-if any-recipients. ${ }^{79}$ Thus, the communication requirement is sometimes tempered by the proviso that the communication must convey a message to a particularized audience. ${ }^{80}$ Alternatively, we might formulate this proviso as requiring the communication to entail the potential of conveying a message, either to the right audience or to anyone who takes the time to acquire the ability to decode it:

In all three court challenges to software export restrictions, the plaintiffs asserted that the source code at issue was comprehensible to computer programmers and conveyed ideas to other programmers. ${ }^{81}$ Indeed, Bernstein argued that he could not convey his ideas to other computer scientists without giving them access to his source code, and that publication of a description of the code in a paper was not enough. ${ }^{82}$ This argument certainly carries some superficial appeal. Computer programmers are undoubtedly expressing something when they compose the code that comprises software. They think carefully about what they are composing. That careful thought, some of which may include very innovative ideas, is transcribed into the notation of some computer language, such as Cobol, Fortran, Basic, C, or Perl. Other programmers can read the resulting code and decipher the logic that went into its composition.

Dist., 393 U.S. 503, 508 (1969) (holding that a black armband worn during the Vietnam era was "a silent expression of opinion" that was "akin to pure speech").

78. "[A] narrow, succinctly articulable message is not a condition of constitutional protection, which if confined to expressions conveying a 'particularized message' . . . would never reach the unquestionably shielded painting of Jackson Pollock, music of Arnold Schoenberg, or Jabberwocky verse of Lewis Carroll." Hurley, 515 U.S. at 569.

79. In a revealing thought experiment, John Searle hypothesizes the activity of a non-Chinesespeaking individual after he is locked in a room and confronted with Chinese writing from the outside. John Searle, Minds, Brains, and Programs, 3 BEHaV. \& BRAIN SCi. 417 (1980); see also WiLliAM POUNDSTONE, LABYRINTHS OF REASON 227-37 (1988) (describing and discussing Searle's hypothetical). The individual responds without understanding the writing by means of a book of formal rules detailing what characters to use in response to certain other characters. Observers outside the room cannot tell from the responses whether or not the individual inside speaks Chinese. Searle, supra, at 418 . The ${ }^{a}$ Chinese Room" scenario underscores that the Chinese characters have meaning, even if a particular recipient cannot understand them and responds without understanding.

80. See Spence, 418 U.S. at 410-11 ("An intent to convey a particularized message was present, and in the surrounding circumstances the likelihood was great that the message would be understood by those who viewed it.").

81. See Junger v. Daley, 8 F. Supp. 2d 708, 717 (N.D. Ohio 1998); Karn v. United States Dep't of State, 925 F. Supp. 1, 9 (D.D.C. 1996); Bemstein v. United States Dep't of State, 922 F. Supp. 1426, 1435 (N.D. Cal. 1996).

82. Bernstein v. United States Dep't of State, 974 F. Supp. 1288, 1293 (N.D. Cal. 1997). 
Even the terms used to describe programming-"read," "write," "language," "code"-evoke associations with the familiar process of communication via speech or press.

But the need to communicate ideas to other researchers is a poor reason to favor the export of software over the export of printed publications describing the software. After all, while the First Amendment may protect a report describing a scientist's research, it is doubtful that the First Amendment prohibits the regulation of the research materials. For example, much like software, nucleic acids embody and transmit information to the biological machinery of a cell. ${ }^{83}$ Absent some clear and present threat to national security, a scientist who-discovers or constructs a DNA sequence probably has a First Amendment right to publish and communicate that sequence to other scientists, including scientists outside the United States. ${ }^{84}$ It does not follow, however, that the scientist has the right to share the embodiment of that information in chemical form with colleagues outside the United States; the government can restrict the movement and dissemination of such materials if, for example, they are embodied within organisms that may prove pathogenic or ecologically destructive. To be sure, there is nothing like the real thing, and it may be that other scientists could more clearly understand the concepts and principles embodied in a recombinant DNA molecule if they could study the physical molecule or its host, rather than a published report about them. But it is unclear how researchers would have any right to obtain the DNA materials embodying a scientific concept, as opposed to a report about the concept. ${ }^{85}$ Instead, it seems that the government has established

83. See Jeremy CAmpBell, Grammatical MaN $91-98$ (1982) (describing the informational capacity of DNA).

84. See Bd. of Trustees of Leland Stanford Junior Univ、 v. Sullivan, 773 F. Supp. 472 (D.D.C. 1991) (holding that the U.S. government could not require Stanford University to waive its right to publish the results of government sponsored artificial heart research); $c f$. United States v. Progressive, Inc., 467 F. Supp. 990, 996 (W.D. Wis. 1979) (concluding that because of risk to national security, publication of technical information about a hydrogen bomb fell within an "extremely narrow exception to the rule against prior restraint").

85. At least some commentators have postulated a "right to research" based upon the First Amendment. See, e.g., Richard Delgado \& David R. Millen, Gad, Galileo, and Government: Toward Constitutional Protection for Scientific Inquiry, 53 WASH. L. REV. 349 (1978); John A. Robertson, The Scientist's Right to Research: A Constitutional Analysis, 51 S. CAL. L. REV. 1203 (1977); see also Harold P. Green, Constitutional Implications of Federal Restrictions on Scientific Research and Communication, 60 UMKC L. REv. 619, 626-42 (1992) (discussing the limits of a national security exception to freedom of scientific communication). But see Gary L. Francione, Experimentation and the Marketplace Theory of the First Amendment, 136 U. PA. L. REV. 417 (1987) (reviewing First Amendment theories on rights to scientific research and asserting that experimentation is not communication in itself). A general overview of the literature is given by Roy G. Spece, Jr. \& Jennifer Weinzierl, First Amendment Protection of Experimentation: A Critical Review and Tentative Synthesis/Reconstruction of the Literature, 8 S. CAL. INTERDISC. L.J. 185 (1998). 
a broad power to regulate access and use of the materials involved in scientific research, whether those materials comprise pathogenic organisms, ${ }^{86}$ animal models, ${ }^{87}$ human subjects, ${ }^{88}$ toxic solvents, ${ }^{89}$ or fissile materials..$^{90}$

In order to justify unregulated dissemination of materials such as DNA or computer code, as opposed to dissemination of printed reports about them, the cryptography plaintiffs have made the more radical claim that the materials themselves comprise speech..$^{91}$ The essential trouble with this argument has been identified by the Supreme Court in the past: "[I]t is possible to find some kernel of expression in almost every activity a person undertakes-for example, walking down the street or meeting one's friends at a shopping mall-but such a kernel is not sufficient to bring the activity within the protection of the First Amendment."92 Similarly, if a utilitarian object such as encryption software contains more than a mere kernel of speech, then it is difficult to see where the confines of the label "speech" will be found. ${ }^{93}$

After all, my automobile, my running shoes, my table cutlery, and essentially every other object that surrounds me in an industrialized society is the embodiment of some artisan's or engineer's design. Industrial engineers are undoubtedly expressing something when they design the circuitry, shape, or structure of everyday items. The designers think carefully about what they are composing. That careful thought, some of

86. See, e.g., 40 C.F.R. pts. 700, 720, 721, 723, 725 (1992) (final rule for Environmental Protection Agency oversight of recombinant microbes under the Toxic Substances Control Act); see also 51 Fed. Reg. 16,958, 16,960 (May 7, 1986) (NIH Guidelines on Pathogen Research). See generally Planned Introduction of Biotechnology Products Into the Environment, 57 Fed. Reg. 6,753 (Feb. 27, 1992); Planned Introduction Into the Environment of Organisms With Modified Hereditary Traits, 55 Fed. Reg. 31,118 (July 31, 1991); Coordinated Framework for Regulation of Biotechnology, 51 Fed. Reg. 23,302 (June 26, 1986) (all proposing policies for federal agencies reviewing biotechnical research and products).

87. See, e.g., 9 C.F.R. $\$ \$ 2.30-2.40$ (1997) (federal regulations on animal research).

88. See, e.g., 45 C.F.R. pt. 46 (1998) (federal regulations on human subjects research).

89. See, e.g., 29 C.F.R. § 1910.1450 (1999) (Occupational Safety and Health Administration laboratory standards).

90. See, e.g., 42 U.S.C. $\$ \$ 2011-2997$ (1994) (federal statutes on fissile materials).

91. Junger v. Daley, 9 F. Supp. 2d 708, 715 (N.D. Ohio 1998) ("The most important issue in the instant case is whether the export of encryption software code is sufficiently expressive to merit First Amendment protection."); Kam v. United States Dep't of State, 925 F. Supp. 1, 9 (D.D.C. 1996) ("The plaintiff argues the [cryptographic] diskette should be considered 'speech' for the purpose of First Amendment analysis . . . ."); Bernstein v. United States Dep't of State, 922 F. Supp. 1426, 1434-36 (N.D. Cal. 1996) (rejecting the defendants' proposition that "the source code, as a functioning cryptographic product, is not intended to convey a particular message”).

92. City of Dallas v. Stanglin, 490 U.S. 19, 25 (1989).

93. See Julie E. Cohen, A Right to Read Anonymously: A Closer Look at "Copyright Management" in Cyberspace, 28 CONN. L. REv. 981, $1004 \mathrm{n} .90$ (1996) (noting with regard to the result in Bernstein that "it is hard to imagine a limiting principle, and wholly implausible to contend that First Amendment protection extends to everything one does and sees"). 
which may include very innovative ideas, is translated into embodiments of steel, cloth, or latex. Other designers can examine the resulting object and decipher the logic that went into its composition. Particularly clever or efficient choices and design innovations may display "elegance" that will be appreciated by other engineers. Thus, the final product of such industrial design choices, functional as it may be, in a sense communicates the ideas of the artisan or engineer, and so under this argument constitutes a sort of speech.

This argument should not be mistaken for a reductio ad absurdum of the Bernstein court's reasoning. In a very broad sense, the absurd conclusion may in fact be correct-technological artifacts, including software, are value-laden and under some definitions could constitute speech. Indeed, this assumption regarding embedded values forms the basis for some of the humanities; such studies assume that artifacts, whether arrowheads or cathedrals or Nash Ramblers, reveal something about the thought processes and cultural milieu of the creators. Neither is the expression of such values through artifacts socially trivial. Technological design choices are not necessarily choices about durability, manufacturing cost, or consumer appeal-although even such utilitarian choices assume certain values. Technologies embody the values of their creator, and the values thus embodied may include social values otherwise unassociated with the artifact itself. In some cases, such embodiment of cultural values in artifacts is explicit or premeditated. For example, Winner cites the low-hanging overpasses on Long Island expressways, which were intentionally designed by their architect, Robert Moses, to preclude the passage of buses. ${ }^{94}$ The bridges therefore preclude lowincome public transportation riders-primarily African-Americans-from reaching Long Island parks.

We may expect that such biases will be embedded as much in speechrelated technologies as in any other technology. Marshall McLuhan's famous maxim that "the medium is the message" declares that the sociological and psychological impact of a medium lies as much in the way it delivers content as it does in the content itself. To illustrate, Wajcman discusses how nineteenth-century Linotype typesetting machines defined social roles within the typesetting and printing industry because the design of the machine inseparably combined the skilled and unskilled work of type compositor and distributor. ${ }^{96}$ As a more modern example, Hofmann discusses how dedicated word processors of the early 1980s, such as the Wang Writer, were designed around certain assumptions about the duties

94. Landon Winner, Do Artifacts Have Politics?, 109 DAEDALUS 121, 123-24 (1980).

95. MARShAll MCLUHAN, UNDERSTANDING THE MEDIA: THE EXTENSIONS OF MAN 7 (1964).

96. JUDY WAJCMAN, FEMINISM CONFRONIS TECHNOLOGY 50-51 (1991). 
and abilities of secretaries, the intended users. ${ }^{97}$ Users were excluded from system functions such as adding, deleting, or renaming files, and as a result the primarily female secretaries were constrained in the degree of task control and skill development possible in their jobs. Thus, historians of technology regard artifacts as being "inscribed" with speech, ${ }^{98}$ and information technologies, having been specifically designed to facilitate communications, would seem to be particularly so "inscribed." 99

Although the value-laden nature of technology is described in expressive terms, values embedded in technology are primarily expressed through function or result, rather than communicative expression. Even in the case of the expression of Robert Moses's racism through the overpasses he designed, the expression of which we speak appears to be functional rather than communicative. The overpasses express racism by physically excluding buses, not by conveying racist sentiments or arguments to the mind of another individual. Indeed, one suspects that it is only because the overpasses did not overtly communicate racism that they were instantiated in stone; had they communicated the idea of racism, rather than implententing a probably unexpected racist result, they might never have been constructed. ${ }^{100}$ Similarly, although the Wang Writer niay have embodied misogynist values, it does not appear to have expressly communicated its designers' sexism, at least not at any level of conscious cognizance. Such functional "expression" appears to lie within the expressive kernel that does not rise to the level of First Amendment protection.

But in some instances the question of artifactual expression extends beyond intrinsic expression of the values embedded in the artifact, as in the nore problematic question raised by machines explicitly designed to communicate with humans. We might conjure examples of a variety of

97. Jeanette Hofmann, Writers, Texts and Writing Acts: Gendered User Images in Word Processing Software, in The Social Shaping OF TECHNOLOGY 222 (Donald Mackenzie \& Judy Wajcman eds., 1999); see also Jane Barker \& Hazel Downing, Word Processing and the Transformation of Patriarchal Relations of Control in the Office, in THE SOCIAL SHAPING OF TECHNOLOGY, supra, at 156-62.

98. Indeed, the metaphor of writing is so pervasive that Woolgar describes artifacts as texts that allow different interpretations, and Latour speaks of artifacts encoded with scripts that are translated by activity involving the artifact. See Steve Woolgar, The Turn to Technology in Social Studies of Science, 16 Scl. TECH. \& HuMAN VALUES 20 (1991); see also Margaret Akrich \& Bruno Latour, $A$ Summary of a Convenient Vocabulary for the Semiotics of Human and Nonhuman Assemblies, in Shaping TEchnology/Building Society: Studies in Sociotechnical Change 259 (Wiebe E. Bijker \& John Law eds., 1992); Bruno Latour, A Door Must Be Either Open or Shut: A Little Philosophy of Techniques, in TECHNOLOGY AND THE POLITICS OF KNOWLEDGE (Andrew Feenberg \& Alastair Hannay eds., 1995).

99. See Phil Agre, The Internet and Public Discourse, FIRST MONDAY, March 1998, at http://www.firstmonday.dk/issues/issue3_3/agre/ (describing the Internet as a meta-medium out of which new media can be constructed).

100. But as Philip Brey notes, the overpasses now discriminate against the more affluent owners of private camper vans, which cannot pass beneath them any more than can public buses. Philip Brey, Artifacts as Social Agents (1998) (unpublished manuscript, on file with author). 
machines, such as kinetic sculptures or music boxes, that communicate expressly rather than intrinsically; such an example was raised by the Bernstein trial court in its comparison of software to a piano roll. There is, after all, a fairly close relationship between piano rolls and software; piano rolls also constitute a type of machine-readable "program." It was not all that long ago that all computer programs were encoded as punched cards or punched tape ${ }^{101}$-exactly like the punched holes of a piano roll. ${ }^{102}$ Piano rolls, of course, express music.by tripping the mechanism of a player piano. In order to do so the rolls have encoded within their sequence of punched holes the music produced by the piano, and the music is fairly clearly the proper subject of First Amendment protection. ${ }^{103} \mathrm{We}$ might properly be disturbed on First Amendment grounds if Congress banned piano rolls or music boxes because of the musical expression that was concomitantly banned.

The piano roll analogy, however, rests on a confusion between mechanisms and outputs. ${ }^{104}$ Certainly the output of a piano roll or a compact disc-i.e., music-is protected speech; similarly, the output of computers, in the form of text, graphics, or sound, may frequently be protected speech. This does not necessarily mean that the mechanism producing the output is itself speech. Facilitating expression is not the sanie as constituting expression. Newsprint and ink are not speech, nor yet is uncomposited movable type, although all of these may convey speech and so are deserving of First Amendment consideration in their own right. Indeed, something as mundane as a newspaper rack might fall into the category of speech-facilitating devices. ${ }^{105}$ But the function of the news rack is quite separable from the expression that it carries, as are the values latent in its design.

We might therefore conclude with some confidence that embedded technological expression is at best the sort of kernel described by the Supreme Court, and not the type of expression shielded by the First

101. STEVen Lubar, INFOCUltuRE 357 (1993).

102. Piano rolls were one of the direct ancestors of computer punch cards. Id.; see also JAMES BURKE, CONNECTIONS 108-13 (1978) (describing the evolution of computers from musical devices to tabulating machines). Programming of early mechanized computing devices was controlled by punched paper rolls or punched cards that allowed wires to poke through according to the pattern of holes. Herman Hollerith developed this method for storing the data of the 1890 U.S. Census. Id. at 112-13; LUBAR, supra note 101, at 301-02. Hollerith got the idea from the Jaquard loom, a mechanized weaving device that encoded instructions for complex weaving designs in punched sheets of paper. JAMES BURKE, THE PINBALL EFFECT 112 (1996). Hollerith's company later produced his punched-card tabulating machines under the name International Business Machines ("IBM"). Id. at 113.

103. See Ward v. Rock Against Racism, 491 U.S. 781, 790 (1989) (“Music, as a form of expression and communication, is protected under the First Amendment. ${ }^{n}$ ).

104. See Dan L. Burk, Copyrightability of Recombinant DNA Sequences, 29 JURIMETRICS J. 469 , 510-11 (1989).

105. See Plain Dealer Publ'g Co. v. City of Lakewood, 794 F.2d 1139, 1143 (6th Cir. 1986). 
Amendment. It seems clear that Congress has the authority to mandate that the height of bridge overpasses be greater than nine feet for financial, safety, or other reasons, let alone the ability to set such standards in order to prevent racially discriminatory preclusion of public transportation from a given community. In so constraining artifactual design parameters, it might be said that Congress is suppressing certain kinds of expression-the architect of the bridge would be unable to give artifactual form to his racial prejudices. But this is by no means the type of prior restraint that would concern us if Congress forbade the printed publication of racist speech. ${ }^{106}$ Similarly, congressional restriction of the function of software does not offend the First Amendment, even if it constrains the expression of values enibedded in the artifact.

\section{Expression and Function}

The analysis to this point hints that we might essay to separate expression from artifact, or at least protected expression from artifact, bifurcating genetic information from genetic substrate, music from piano roll, cryptographic concept from cryptographic software. But this handy distinction assumes that we can tell what is or is not an artifact. It is tempting, for example, to approach the problem of software expression by analogizing the source code at issue in Karn, Bernstein, and Junger not to a bridge itself, but only to the bridge design. Computer software is typically written in a high-level computer language that is easily manipulated by humans; this source code is then compiled into machinereadable object code that the machine can execute. ${ }^{107}$ Similarly, industrial designers create designs-computerized drawings today, blueprints in an earlier era-that seem clearly to be speech in the First Amendment sense, even if the object of the designs may not be. We might plausibly attempt to draw a distinction between state regulation of blueprints and state regulation of the artifacts depicted in the blueprints, effectively bifurcating the object from all or most of the expression. If the First Amendment forbids state regulation of blueprints or other industrial drawings, then even if the object of the design is banned or heavily regulated we might still have some confidence that the expressive activity of designers will remain relatively unconstrained.

106. Cf. R.A.V. v. City of St. Paul, 505 U.S. 377 (1992) (holding a city ordinance prohibiting racially discriminatory speech unconstitutional).

107. See Jean E. Sammet, Programming Languages, in ENCYCLOPEDIA OF COMPUTER SCIENCE 1121, 1121-23 (Anthony Ralston \& Edwin D. Reilly eds., 3d ed. 1993) (describing pure binary language, which is very impractical, noting that programmers may use a high-level language despite having no knowledge of machine code, and describing the compiling process); Andrew Johnson-Laird, Software Reverse Engineering in the Real World, 19 U. DAYTON L. REV. 843, 856-59 (1994) (describing the process by which source code is created by a programmer, and then translated into computer-readable object code). 
Thus, one might be drawn to say that if Congress can regulate the bridge or the object code, but not the drawing or the source code, then the dividing line between expression and function, between speech and artifact, can be preserved. The racial bigotry of Robert Moses would of course not be fully expressed by drawings of low overpasses, but perhaps this does not concern us overmuch; unlike a racist sculptor who could claim a First Amendment right to both design and build an offensive statue, the racist overpass designer cannot claim a constitutional right to instantiate the physical function of his design. We would presumably not permit the full expression of racial bigotry in some type of device built to maim or kill racial minorities either, even if we permitted bigots to draw or describe the device. At best, expression of a view or opinion by physical construction would seem to come under the $O^{\prime} B r i e n$ test for symbolic speech. Such a rule may simply throw the distinction into fuller relief: bigots can write about their prejudices without state interference, or about artifacts that would implenient their prejudices, or even publish designs of such artifacts, but cannot necessarily nianufacture or produce the devices of such design without state regulation.

As applied to coniputer programs, however, this argument is faulty because the relationship between source code and object code is entirely different than that between a blueprint and the artifact it depicts. The fact that some source code must be conipiled before being executed is immaterial to the presence or absence of expression in the corresponding object code. Source code is simply uncompiled or uninterpreted object code, a step away from machine execution. Also, the difficulty of reading the program in object code does not nuatter for expressive purposes; as a theoretical matter, it is certainly possible, though enormously inconvenient, for a programmer to program in machine-readable code. ${ }^{108}$ The expression of the programmer would be the same in either case. ${ }^{109}$ Certainly the machine-readable version will be difficult to understand, even to a programmer, but so is modern art and atonal music. ${ }^{110}$ The artificiality of the purported distinction becomes even more apparent in the case of uncompiled languages, or intermediate languages, such as Perl, in which the programming script is executed without conversion to machine-readable code. ${ }^{111}$

108. See, e.g., Anthony L. Clapes, Confessions of an Amicus Curiae: Technophobia, Law, and Creativity in the Digital Arts, 19 U. DAYTON L. REV. 903, 941 \& n. 188 (1994) (providing an example of a programmer reading and understanding object code).

109. Trained engineers can also glean ideas from object code; this is what occurs when software is decompiled and reverse engineered. See id. Understanding the operation of the program from examination of object code is much more time-consuming and inconvenient than it would be from examination of the corresponding source code. See Johnson-Laird, supra note 107, at 856-59.

110. See supra note 77.

111. Although many computer languages require conversion of the routine to machine-readable form, some languages are interpreted rather than compiled; that is, the script is read by a program 
Nonetheless, this purported distinction between design and artifact was adopted by the trial court in Bernstein and implicitly adopted by the appellate panel in that case, analogizing source code to "instructive" works, such as cookbooks and blueprints, that give direction on how to carry out a process. ${ }^{112}$ The trial court concluded that if functional texts, such as recipes and the like, are protected by the First Amendment, so too are functional texts that give directions to a machine. ${ }^{113}$ The appellate majority similarly reasoned that texts may be protected under the First Amendment even if they are functional. ${ }^{114}$ Extending this analysis to DeCSS, one might reason that a hacker could post instructions in English on how to circumvent DVD copy protection. Such instructions might arguably be used for an illegal purpose, but with only rare exceptions, instructions on how to perform illegal acts are constitutionally protected speech. ${ }^{115}$ If source code instructions are equivalent to English instructions, then perhaps an injunction prohibiting the dissemination of the code is as much an unconstitutional prior restraint as an injunction on the English instructions.

This attempt to equate functional texts with source code is fundamentally flawed because it conflates two different meanings of the word "instruction." Instructions to a computer are not the same as instructions to a human. Unlike recipes or "how to" manuals, source code instructions do not inform humans how to carry out a process. Instead, source code instructions command the arrangement of voltages in computational registers, a process which humans typically do not follow. Moreover, the

called an interpreter, which executes pre-designated commands according to the script. See, e.g., Charles Eaker, Forth, in ENCYCLOPEDIA OF COMPUTER SCIENCE 565, 565 (Anthony Ralston \& Edwin D. Reilly eds., 3d ed. 1993) (analyzing the way in which an interpreter works). BASIC and Java are examples of computer languages that have been implemented in this fashion. See, e.g., HARVEY G. LORD, 2 PROGRAMMING FOR REAL 101-02 (1985) (BASIC); Bill Jenners, The Java Paradigm (October 1996), at <http://www.javacats.com > (Java). Perl, anotherpopular programming language, is nejther compiled nor interpreted, but converted into an intermediate form before being executed. See MARTIN C. BROWN, PERL: THE COMPLETE REFERENCE 6-8 (1999).

112. Bemstein v. United States Dep't of State, 922 F. Supp. 1426, 1435 (N.D. Cal. 1996); Bemstein v. United States Dep't of Justice, 176 F.3d 1132, 1141-42 (9th Cir. 1999).

113. Bernstein, 922 F. Supp. at 1435.

114. Bernstein, 176 F.3d at 1141-42.

115. See, e.g., United States v. Progressive, Inc., 467 F. Supp 990 (W.D. Wis. 1979) (enjoining the publication of instructions on how to build nuclear devices). Generally, advocacy of criminal action is protected speech unless it is imminent incitement of lawlessness. Brandenburg v. Ohio, 395 U.S. 444, 448-49 (1969). Detailed instructions rendered in furtherance of a crime may be constitutionally penalized if closely tied to the criminal act and accompanied by criminal intent. United Statcs v. Kelly, 769 F.2d 215, 217 (4th Cir. 1985) (holding that instructions aiding and abetting tax fraud were not protected by the First Amendment); United States v. Buttorff, 572 F.2d 619, 623-24 (8th Cir. 1978) (same); see also Umited States v. Bamett, 667 F.2d 835, 842-43 (9th Cir. 1982) (holding that the First Amendment did not insulate the publisher of instructions on illegal drug manufacture from search and seizure). 
human recipient of written instructions may choose not to execute them. ${ }^{116}$ The source code may be read by a human, who may understand what processes it entails, but the code remains abstract machinery-it will be executed by the machine automatically and involuntarily, after being automatically and involuntarily compiled into the proper format. In short, instructions to a human merely describe how to perform a task whereas software instructions actually are a part of the machine that executes the task.

This mechanical character of software becomes clearer when it is understood that any function that can be implemented in software can be implemented equally well in hardware. ${ }^{117}$ The analogy of software to blueprints or cookbooks is largely an illusion created by our deployment of universal machines-that is, machines capable of performing a variety of functions when configured in different ways by computer software. The software-configured universal machine is equivalent to a dedicated machine hardwired to perform the same task. ${ }^{118}$ Software is a convenient method of configuring a universal machine to perform certain functions; however, we might instead have chosen to employ individual machines dedicated to word processing, statistical analysis, or other functions. Stated differently, Junger or Bernstein or Karn might equally well have built computer hardware to perform encryption functions, but had they done so, it would have been much less appealing to argue that these devices were protected speech, any more than to make the same argument for Robert Moses's bridge.

This is the crux of the problem over the characterization of software. Far from being the instruction manual to an intricate and complicated machine, computer code is in fact the machine itself. Software is not a text, it is a machine built of text. Just as physical machines are built from tangible media such as wood, steel, and plastic, programs are built from source code. One group of commentators has put this in the clearest possible terms:

116. As Professor Karjala succinctly explains:

The often used analogy of computer programs to food recipes is inapt. It is true that light reflecting off the recipe causes neural impulses in the human brain, resulting in understanding of the instruction 'Add 1 cup milk,' but the recipe does not cause the milk to be added and the cook remains free to add 2 cups of milk, or $1 / 2$ cup or none at all, as he or she chooses. A computer, on the other hand, has no choice concerning the execution of instructions in a program, any more than water has a choice between flowing uphill or downhill.

Dennis S. Karjala, Copyright, Computer Software, and the New Protectionism, 28 JURIMETRICS J. 33, 37 n.3 (1987).

117. Pamela Samuelson et al., A Manifesto Concerning the Legal Protection of Computer Programs, 94 COLUM. L. REV. 2308, 2319 (1994).

118. Id. at $2320 \&$ n.34. 
To put the point starkly: no one would want to buy a program that did not behave, i.e., that did nothing, no matter how elegant the source code "prose" expressing that nothing. . . .

The goal of a programmer designing software is to achieve functional results in an efficient way. While there may be elements of individual style present in program design, even those style elements concern issues of industrial design, e.g., the choice of one or another programming technique or the clarity (or obscurity) of the functional purpose of a portion of the program. ${ }^{119}$

Thus, instructions to humans and instructions to machines are functional in entirely different ways. Recipes and blueprints are functional in the sense that human language is always functional: language conveys information to humans. ${ }^{120}$ The Ninth Circuit majority in Bernstein is in a sense quite correct that functional speech falls under the protection of the First Amendment; essentially all the speech protected by the First Amendment performs this communicative function. Indeed, the debate over software as speech in a sense raises to new heights the venerable literary debate as to whether text constitutes Logos - a thing said, or Poiema-a thing made. ${ }^{121}$ Language is by its nature both functional and expressive because its function is to convey meaning through a rich mixture of connotative, denotative, and imperative modes. ${ }^{122}$ Recipes and instruction manuals are only the most obvious examples of linguistic function because in such examples linguistic operation has been stripped down to a predominant imperative mode. ${ }^{123}$ But when any language is well crafted, its words and phrases are carefully chosen to optimize that function.

There is some appeal to the conclusion that computer code is in a similar way both functional and expressive because a human observer can extract meaning from the code-readily in the case of source code, painstakingly in the case of object code. But, in contrast to the crafting of human language, when computer code is well crafted its routines are carefully chosen so as to optimize the speed and efficiency of a machine's operation-not to inform a reader. ${ }^{124}$ The function of computer code is

119. See Samuelson et al., supra note 117 , at $2317,2328-29$ (emphasis added).

120. Cf. 17 U.S.C. $\$ 102$ (b) (1994) (excepting "any idea, procedure, process, system, method of operation, concept, principle, or discovery" from copyright protection).

121. See C.S. LEWIS, AN EXPERIMENT IN CRITICISM 132-37 (1961).

122. See Roman Jakobson, LANGUage in Literature 66 (Krystyna Pomosko \& Stephen Rudy eds., 1987) (investigating the several functions of language, and analyzing how the expressive aspect of language can impact its functional meaning).

123. In its imperative function, a message seeks to elicit a response from the recipient. Id.

124. Some philosophers have in fact argued that the fundamental difference between human intelligence and artificial intelligence is the ability to perceive meaning. See Searle, supra note 6 , at 
not to convey meaning, but to configure a virtual machine. The computer code actually determines the type of machine that the computer will become. Unlike instructions to humans, computer instructions are functional in the sense that they physically behave, much like Robert Moses' overpasses physically behave. ${ }^{125}$ Blueprints may instruct humans how to build a machine, but computer code is the machine.

Courts have long recognized a version of this distinction between functional speech and instructive speech in the context of injuries arising from instructions in "how-to" manuals. ${ }^{126}$ In general, the law of products liability declines to find such texts defective because they do not behave, but rather are meant to be read. ${ }^{127}$ Significantly, the exception

422 (arguing that machines merely manipulate symbols without understanding them); but see also Douglas R. Hofstadter, Reflections, in THE MIND's 1373 (Douglas R. Hofstadter \& Damiel C. Dennett eds., 1981) (critiquing Searle's analysis). I leave for another discussion in some different forum the question whether the distinction between human-readable and machine-readable instructions as discussed here might collapse if a sufficiently sophisticated machine could perceive "meaning," and whether the human brain is best characterized as such a machine.

125. Thus, Larry Lessig rightly describes computer software as defining a virtual architecture of computer networks, because it constrains human behavior. See, e.g., Lawrence Lessig, Reading the Constitution in Cyberspace, 45 EMORY L. REV. 869, 888-89 (1996); Lawrence Lessig, The Zones of Cyberspace, 48 STAN. L. REV. 1403, 1408-09 (1996); $f$. Lawrence Lessig, The Law of the Horse: What Cyberlaw Might Teach, 113 HARV. L. REV. 501, 543 (1999) (dubbing Robert Moses' overpasses as physical "regulation through architecture"). Some commentators have argued that the physical architecture of buildings deserves First Amendment protection, but that is because of the artistic or aesthetic expression in the structure, not its functional character. See, e.g., John J. Costonis, Law and Aesthetics: A Critique and a Reformulation of the Dilemmas, $80 \mathrm{MICH}$. L. REV. 355, 411-12, 446-47 (1982); Annette B. Kolis, Architectural Expression: Police Power and the First Amendment, 16 URB. L. ANN. 273, 278-79 (1979).

126. See, e.g., Winter v. G.P. Putuam's Sons, 938 F.2d 1033, 1036 (9th Cir. 1991) (holding that a publisher has no liability to a plaintiff who relied upon a book's inaccurate identification of a poisonous mushroom as edible); Jones v. J.B. Lippincott Co., 694 F. Supp. 1216, 1216-17 (D. Md. 1988) (holding that a publisher was not liable to a nursing student injured in treating herself with a hydrogen peroxide enema remedy described in a nursing textbook); Lewin v. McCreight, 655 F. Supp. 282, 283-84 (E.D. Mich. 1987) (holding that a publisher was not liable to plaintiffs injured in an explosion while unixing a mordant according to a book on metalsmithing); Cardozo v. True, 342 So. 2d 1053, 1057 (Fla. Dist. Ct. App. 1977) (holding that a book dealer was not liable for failing to warn the purchaser of a cookbook about a recipe ingredient that was poisonous until cooked); Alm $v$. Van Nostrand Reinhold Co., 480 N.E.2d 1263, 1267 (111. App. Ct. 1985) (holding that a publisher was not liable to a plaintiff injured by a shattered tool while following an instruction in a book on woodcarving); MacKown v. Ill. Publ'g \& Printing Co., 6 N.E.2d 527, 530 (Ill. App. Ct. 1937) (holding that a publisher was not liable for personal injury caused by dandnuff remedy printed in newspaper); Roman v. City of New York, 442 N.Y.S.2d 945, 948 (N.Y. Sup. Ct. 1981) (holding that Planned Parenthood was not liable for a misstatement in a contraceptive pamphlet); Walter v. Bauer, 439 N.Y.S.2d 821,822 (N.Y. Sup. Ct. 1981) (holding that a publisher was not liable for an injury sustained during the performance of an experiment published in a manual); Smith v. Linn, 563 A.2d 123, 127 (Pa. Super. Ct. 1989), aff'd, 587 A.2d 309 (Pa. 1991) (holding that a publisher was not liable for the death of a reader following the "Last Chance Diet"). But see Rice v. Paladin Enter. Inc., 128 F.3d 233 (4th Cir. 1997) (holding that a "how-to" book for hitmen was not entitled to First Amendment protection).

127. RESTATEMENT (THIRD) OF TORTS: PRODUCTS LiABILITY $\$ 19 \mathrm{cmt}$. d (1997) (observing that courts have generally declined to hold publishers liable for information in books because they are information and not products). 
to this liability rule in cases where injuries arise from inaccurate aeronautical charts ${ }^{128}$ is characterized by the courts' assertions that the charts are items "physically used" in the operation of aircraft, equivalent to a broken compass or inaccurate altimeter. ${ }^{129}$ Note that compasses and altimeters are also devices that express or convey information to a reader, but for which issues of speech would unquestionably be subordinate to issues of accuracy and safety, if indeed such devices received any consideration under the First Amendment at all. ${ }^{130}$ Thus, as a matter of products liability, inaccurate texts are not defective for their intended purpose-they are perfectly legible ${ }^{131}$-and, as a matter of negligence law, injuries arising from inaccurate content are proximately separated from the text by the intervening volitional actions of the human reader. ${ }^{132}$

This is not to say that software, though functional, might not convey a certain type of information to the experienced observer. Aside from its functional aspect, the code may incidentally convey to a skilled programmer a sense of its creator's design choices and methodology. Another programmer can surely look at source code, or for that matter object code,

128. See, e.g., Brocklesby v. United States, 767 F.2d 1288 (9th Cir. 1985); Aetna Cas. \& Sur. Co. v. Jeppesen \& Co., 642 F.2d 339 (9th Cir. 1981); Fluor Corp. v. Jeppesen \& Co., 216 Cal. Rptr. 68 (Cal. Ct. App. 1985).

129. See Brocklesby, 767 F.2d at 1294-95; Saloomey v. Jeppesen \& Co., 707 F.2d 671, 676-77 (2nd Cir. 1983); cf. Way v. Boy Scouts of Am., 856 S.W.2d 230, 238-39 (Tex.App.-Dallas 1993, writ denied) (noting cases relying on the physical use distinction, but distinguishing them from the case before the court); see also RESTATEMENT (THIRD) OF TORTS: PRODUCTS LIABILITY $§ 19 \mathrm{cmt}$. d (1997) (“In these cases, the courts emphasized that navigational charts are used for their physical characteristics rather than for the ideas contained in them."); Robert Post, Recuperating First Amendment Doctrine, 47 STAN. L. REV. 1249, 1254 (1995) (surveying cases holding that navigational charts are not speech because of user reliance).

130. One of the implications of taking the Bernstein result seriously may be that defective software falls under the First Amendment shield of the instructional "how-to" manual line of cases, rather than being treated as a product under the aeronautical line of cases. This somewhat disturbing outcome lies beyond the scope of this Article; I will only note that this characterization of informational products is tied to the elaborate mechanisms for disclaiming product fitness warranties under the proposed Uniform Computer Information Transaction Act, formerly known as proposed Uniform Commercial Code Article 2B. Cf. Joel R. Wolfson, Express Warranties and Published Information Content Under Article 2B: Does the Shoe Fit?, 16 J. MARSHALL J. COMPUTER \& INFO. L. 337 (1997) (concluding that the treatment of express warranties should not be extended to licenses of published information content because information is not a good or product).

131. Cf. RESTATEMENT (THIRD) OF TORTS: PRODUCTS LIABILITY $\& 17 \mathrm{cmts}$ a \& c (1997) (noting that while misuse of a product used to be a complete bar to recovery, it is now a factor to be analyzed in diminishing recovery).

132. See RESTATEMENT (SECOND) OF TORTS \$ $440-41$ (1965) (concerning intervening forces). See also Gutter v. Dow Jones, Inc., 490 N.E.2d 898, 902 (Ohio 1986) (holding that the allegation of "mere negligence" against a publisher printing inaccurate information does not state a cause of action in tort because free speech considerations "tilt decidedly in favor of the press"). Cf. McCollum v. CBS, Inc., 249 Cal. Rptr. 187, 196-97 (Cal. Ct. App. 1988) (holding that the plaintiff's suicide, allegedly the result of listening to an Ozzy Osboume song, was not a reasonably foreseeable result of the production of the album). 
and discern the programmer's programming strategy-just as a mechanic examining an automobile engine or an electrician tracing wiring can perceive something of its creator's design choices and engineering strategy from the physical structure of the machine or circuit. ${ }^{133}$ No doubt the signature of the code's construction may be distinctive, often reflecting the idiosyncracies and personality of the creator. But as we have discussed above, this will be true of the functional design choices embedded in any artifact, whether software, hardware, or bridge overpasses. The fact that an engineer "reading" program code appears to be reading textual instructions, rather than tracing logic circuits, is an artifact of the medium from which the program is built. It is not the equivalent of reading a blueprint or recipe. In one case, the engineer is extracting design information from a functional artifact that happens to be composed of text, and in the other, the reader is receiving communication via a nonfunctional instructional text that can have no other purpose than to convey information to that reader.

\section{Software and Copyright}

I have argued in the previous section that because it is functional, rather than useful or instructive, computer software is unlike any text that has previously been subjected to First Amendment scrutiny. To the extent that it may convey technical ideas to a particularized audience, such "communication" differs in degree but not in kind from the expression embedded in other utilitarian artifacts. Attempts to winnow the functional aspect of software from the expressive are likely to be futile, as essentially everything in the code is meant to be functional.

The problem that I have delineated thus far, of separating expression from function in software, is hauntingly familiar to those who have followed the saga of intellectual property rights in computer software. For the past two decades, courts have been struggling with similar issues regarding function and expression in the context of copyright. ${ }^{134}$ This parallel was explicitly employed by the trial judge in Bernstein, who relied upon an explicit copyright analogy to establish the categorization of source code as protected speech. ${ }^{135}$ The same analogy was urged upon the Ninth Circuit Court of Appeals by several amici. ${ }^{136}$ As formulated by

133. See Kajala, supra note 6 at 42 n.3.

134. See, e.g., Computer Assocs. Int'l, Inc. v. Altai, Inc., 982 F.2d 693, 705 (2d Cir. 1992); Apple Computer, Inc. v. Franklin Computer Corp., 714 F.2d 1240, 1253 (3d Cir. 1983).

135. Bernstein, 922 F. Supp. 1436 ("By analogy, copyright law also supports the 'expressiveness' of computer programs. Computer software is subject to copyright protection as a 'literary work.").

136. See, e.g., Brief of Amicus Curiae Garrett Epps, United States v. Bernstein, 176 F.3d 1132 (9th Cir. 1999) (No. 97-16686), available at http://www.eff.org/pub/Privacy/Crypto/Crypto_export /Bernstein_case/Legal/971110_lawprofs.amicus; Brief of Amici Curiae Electronic Privacy Information Center et al., United States v. Bernstein, 176 F.3d 1132 (9th Cir. 1999) (No. 97-16686), available at http://www.eff.org/pub/Privacy/Crypto/Crypto_export/Bernstein_case/Legal/ 971110_epic.amicus. 
the Bernstein trial court and by the amici, the syllogism runs something like this: computer source code is copyrightable, copyright protects expression, therefore source code is expression; the First Amendment protects expression, source code is expression, therefore software is protected by the First Amendment. QED. But despite the appealing simplicity of this reasoning, the analogy to copyrightable expression conceals a variety of troubling complications.

\section{A. Copyright and Speech}

In one sense, such appeals to analogy are entirely understandable. The Bernstein trial judge turned to what is perhaps the only body of law to have previously distinguished expression and function: the law of copyright. But the relationship between copyright and the First Amendment is far more complex than the judge's syllogism reflects, and the copyright precedent regarding expression in software is problematic. Copyright and the First Amendment frequently meet, as they often apply to the same subject matter. ${ }^{137}$ But the relationship between the two legal regimes has generally been a reciprocal or inverse relationship. There has long been a perceived tension between the two. ${ }^{138}$ Copyright constitutes a state-sponsored restraint upon certain types of expression-something that the First Amendment generally forbids. The Supreme Court has indicated that copyright ultimately serves to further First Amendment purposes by providing a financial incentive for creative speech, ${ }^{139}$ but the fact remains that in order to provide that incentive for some speech, other speech is restrained. The copyright doctrine of fair use has been seen as the mediator of this tension, a sort of "safety valve" that ensures the First Amendment right to comment and criticize by using copyrighted expression

137. See Mark A. Lemley \& Eugene Volokh, Freedom of Speech and Injunctions in Intellectual Property Cases, 48 DuKE L.J. 147, 150, $165-66$ (1998) (noting that "[i]n copyright cases . . . preliminary injunctions are granted pretty much as a matter of course," which seriously restricts creative expression).

138. See, e.g., Robert C. Denicola, Copyright and Free Speech: Constitutional Limitations on the Protection of Expression, 67 CAL. L. REV. 283, 284 (1979); Paul Goldstein, Copyright and the First Amendment, 70 ColuM. L. REV. 983, 983 (1970); Melville B. Nimmer, Does Copyright Abridge the First Amendment Guarantees of Free Speech and Press?, 17 UCLA L. REV. 1180, 1180-86 (1970); Lionel S. Sobel, Copyright and the First Amendment: $A$ Gathering Storm?, 19 COPYRIGHT L. SYMP. 43, 63 (1971); Alfred C. Yen, A First Amendment Perspective on the Idea/Expression Dichotomy and Copyright in a Work's "Total Concept and Feel," 38 EMORY L.J. 393, 396-97 (1989); see also Yochai Benkler, Free as the Air to Common Use: First Amendment Constraints on Enclosure of the Public Domain, 74 N.Y.U. L. REV. 354, 356 (1999).

139. See Harper \& Row, Publishers, Inc. v: Nation Enters., 471 U.S. 539, 558 (1985) (“[I]t should not be forgotten that the Framers intended copyright itself to be the engine of free expression. By establishing a marketable right to the use of one's own expression, copyright supplies the economic incentive to create and disseminate ideas." ). 
in ways that might otherwise constitute infringement. ${ }^{140}$ Additionally, limiting doctrines such as copyright's idea/expression dichotomy may similarly mediate the tension between these two constitutional

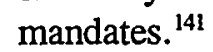

This trade-off between incentive and restriction was seized upon by the Reimerdes trial court in considering the constitutionality of the DMCA anticircumvention provisions. ${ }^{142}$ The judge reasoned that if it is permissible in copyright to suppress some speech in order to encourage other speech, then suppression of whatever expression DeCSS might entail is permissible to protect the copyright incentive for CSS encrypted works. ${ }^{143}$ But the constitutional balance struck in copyright is largely irrelevant to the constitutionality of a provision suppressing source code expression. If DeCSS source code is protected speech, it is speech entirely unrelated to the speech encoded on DVDs, and copyright has little to say about such a trade-off. The copyright bargain contemplates a restriction upon the availability of the speech that is itself created pursuant to the incentive of exclusivity, or in the case of the right of adaptation, to restriction of closely related derivative expression. The copyright bargain does not speak to the larger effects of restriction: whether by suppressing, say, romance novels, we might evoke more independent art films.

Neither does the copyright bargain speak to whether the costs of suppressing source code expression would be offset by concomitant gains in the production of copy-protected works. Certainly the law of copyright has long included a doctrine of contributory infringement that penalizes aiding and abetting infringement, ${ }^{144}$ and the DMCA anticircumvention provisions incorporate a variation of that doctrine. ${ }^{145}$ But these provisions speak to the restriction of devices, not to the restriction of unrelated expression that may have independent speech value. And, indeed, even in the case of devices, both the doctrine of contributory infringement and the DMCA will trade incentive for suppression only when a device fails to offer the public any substantial noninfringing benefit. ${ }^{145}$

140. Id. at 549; see also Goldstein, supra note 138, at 1011 ("The effect of the fair use defense is to excuse otherwise infringing conduct in circumstances where the public interest compels free access.").

141. Harper \& Row, 471 U.S. at 545; Sid \& Marty Krofft Television Prods., Inc. v. McDonald's Corp., 562 F.2d 1157, 1170 (9th Cir. 1977); see also Nimmer, supra note 138, at 1190-93. But see Yen, supra note 138, at 396-97 (expressing skepticism about the adequacy of the idea/expression dichotomy as a First Amendment bulwark).

142. Universal City Studios, Inc. v. Reimerdes, 111 F. Supp. 2d 294, 329 (S.D.N.Y. 2000).

143. Id.

144. See Sony Corp. of Am. v. Universal City Studios, Inc., 464 U.S. 417, 435-42 (1984) (analyzing contributory infringement cases dating back to 1911).

145. 17 U.S.C. $\$ 1201$ (a)(2) (Supp. IV 1998).

146. See 17 U.S.C. § 1201(a)(2)(A), (B) (Supp. IV 1998) (prohibiting trafficking in technology "primarily designed or produced for" or having "only limited commercially significant purpose or use" 
This disjunction between copyright incentives and First Amendment protection reveals the danger of equating the subject matters of the two. By analogizing copyright to First Amendment jurisprudence, the Bernstein and Reimerdes trial court opinions beg the question whether expression for purposes of copyright and expression for purposes of the First Amendment mean the same thing. Certainly the scope of the term as used in both copyright and the First Amendment jurisprudence entails substantial overlap. Yet the scope of expression in copyright and the scope of expression in free speech are not coextensive. Despite the overlap between the two uses of the term, the First Amendment clearly protects some types of expression that the copyright statute does not cover. For example, unfixed expression, such as nude dancing or flag burning, may constitute protected speech, ${ }^{147}$ but is not within the scope of federal copyright law. ${ }^{148}$ Unoriginal expression might also be protected by the First Amendment, but it is not by copyright. ${ }^{149}$ Similarly, copyright may protect expression that is not covered by the First Amendment. For example, the Supreme Court has held that obscene expression falls outside the scope of the First Amendment; ${ }^{150}$ however, lower courts have held that such materials may nonetheless be subject to copyright. ${ }^{151}$ Thus, the universe comprising expression or speech is broader than the scope of either copyright or the First Amendment. The law of copyright and the law of free speech are directed toward different subsets of that universe in order to achieve different purposes. Software, even if expressive in some sense, could well lie within the realm of copyright and not of the First Amendment, or outside both. This disjunction of scope militates against uncritical application of conclusions drawn regarding software in the copyright context to analysis of software in the First Amendment context.

\section{B. Copyright and Communication}

Even if the correspondence between expression in copyright and First Amendment jurisprudence is not perfect, evidence of some congruence

other than to circumvent copyright control technology); Sony, 464 U.S. at 442 (selling devices does not constitute contributory infringement if the devices are "capable of substantial non-infringing uses").

147. See supra notes $74-75$ and accompanying text.

148. See 17 U.S.C. $\$ \S 101,102$ (1994 \& Supp. IV 1998) (pronouncing that copyright subsists in fixed works and defining "fixed").

149. See 17 U.S.C. $\$ 102$ (1994) (requiring that the protected work be original). Indeed, the Supreme Court has held that originality is a constitutional requirement under the Copyright Clause. See Feist Publ'ns, Inc. v. Rural Tel. Serv. Co., 499 U.S. 340, 345 (1991).

150. See, e.g., Miller v. California, 413 U.S. 15 (1973).

151. See, e.g., Jartech, Inc. v. Clancy, 666 F.2d 403 (9th Cir. 1982) (holding that obscenity is not a defense to a copyright infringement claim under the Copyright Act of 1976); Mitchell Bros. Film Group v. Cinema Adult Theater, 604 F.2d 852 (5th Cir. 1979) (concluding that the 1909 copyright statute contained no explicit or implicit bar to copyright in obscene works). 
between the two areas may be found by examining the criterion of "communication to a particularized audience" sometimes employed by the Supreme Court to essay for protected expression. In copyright, the question of communication to an audience is not a new one; it stretches back at least to the Supreme Court's decision in White-Smith Music Publishing Co. v. Apollo Co. ${ }^{152}$ which might in some senses be considered the first computer software case. The Court in White-Smith was asked to determine whether a player piano roll, which embodied as punched holes the music to a copyrighted song, infringed the copyright in the song. The Court ruled that the piano roll did not infringe the copyright because it did not communicate with a human being, reasoning that even those familiar with piano rolls could not read the music encoded by the holes. ${ }^{153}$ This result prompted Congress, to subsequently amend the copyright statute to protect piano rolls, phonograph records, compact discs, and other "machine readable" musical embodiments as a new category of copyrightable work. ${ }^{154}$

Similar communication arguments were subsequently raised squarely in the context of computer software. For example, the accused infringer of an operating system in Apple Computer, Inc. v. Formula International, Inc. ${ }^{155}$ argued that computer operating systems are ineligible for copyright protection because they do not communicate with human beings. ${ }^{156}$ Operating systems are designed to coordmate the operations of the machine without observation or intervention of the user; indeed, the hallmark of a successful operating system is that the user is unaware of its functioning. This is also true to a greater or lesser extent of almost all computer programs. In the case of application programs with which the user may interact, the underlying computer code is rarely perceived by software users. Rather, the user sees the program's output, which is a quite different matter. 157

The court in Formula rejected the communication argument, declaring that "never has the copyright act required that the expression be communicated to a particular audience." 158 This declaration is literally

152. 209 U.S. 1 (1908).

153. Id. at 18.

154. Sound Recording Amendment, Pub..L. No. 92-140; 85 Stat. 391, 391-92 (1971).

155. 725 F.2d 521 (9th Cir. 1984).

156. Id. at 524.

157. See Computer Assocs. Int'l, Inc. v. Altai, Inc., 982 F.2d 693, 703 (2d Cir. 1992) (remarking that "screen displays . . . represent products of computer programs, rather than the programs themselves").

158. Formula, 725 F.2d at 525 . While this may arguably be true under the 1976 Copyright Act, it was certainly not necessarily the view under previous versions of the statute. See, e.g., Data Cash Sys., Inc. v. JS \& A Group, Inc., 480 F. Supp. 1063 (N.D. III. 1979), aff'd on other grounds, 628 F.2d 1038 (7th Cir. 1980) (holding a computer program uncopyrightable under the 1909 Copyright Act 
correct since the statute nowhere sets out such requirement. It is also correct in another important manner: since the accession of the United States to the international Berne Convention, copyright protection arises spontaneously upon fixation of a creative work in a tangible medium of expression. ${ }^{159}$ Under the rather peculiar metaphysics of copyright law, the author holds rights in the work, a sort of idealized Platonic Form, rather than in an embodiment of the work, known as a copy. ${ }^{160}$ One can therefore envision the case of an artist, who goes into a locked room alone, paints a painting, and then immediately destroys it. Under the statute, the artist is an author and copyright subsists in the work, although no copy exists from which anyone might infringe. The work has not been, and need not be, communicated to an audience for rights to attach.

Despite its resemblance to inquiries over the noise of the proverbial unobserved tree falling in the forest, this little thought experiment underscores the lack of any actual communicative requirement for a work to qualify as copyrightable expression. ${ }^{161}$ Indeed, the Suprenie Court has indicated that otherwise uncommunicated works niay deserve a heightened degree of protection against copyright infringenient. ${ }^{162}$ Unauthorized dissemination of otherwise unpublished manuscripts, correspondence, and papers has been harshly penalized, even when the material at issue is of significant public interest or social importance. ${ }^{163}$ The Court has suggested that infringement of secret works is a serious matter in part because it interferes with the reward incentive of copyright by robbing the author of the opportunity to calibrate the timing of the work's public release. ${ }^{164}$

Still, as a policy matter, the lack of any communication requirement in copyright is soniewhat counterintuitive given that the stated social goal of the copyright regime is to foster creation and dissemination of works to the public. Yet presumably the uncommunicated notes, private diaries,

because it was unintelligible to human readers). Note that the Data Cash holding was based on similar reasoning reached by the Supreme Court with regard to the "piano roll" in White-Smith Publ'g Co. $v$. Apollo Co. See supra text accompanying note 153.

159. 17 U.S.C. $\S 102$ (1994).

160. 17 U.S.C. $\$ 101$ (1994).

161. Cf. Reiss v. Nat'l Quotation Bureau, Inc., 276 F. 717, 718-19 (S.D.N.Y. 1921) (holding that copyright may subsist in meaningless nonsense words).

162. Harper \& Row, Publishers, Inc. v. Nation Enters., 471 U.S. 539, 554 (1985); cf. Salinger v. Random House, Inc., 811 F.2d 90, 100 (2d Cir. 1987) (stating that an author has the right to "protect the expressive content of his unpublished writings").

163. For example, in Harper \& Row, the material that was published without authorization dealt with the controversial pardon of former President Richard Nixon by his successor, Gerald Ford. Harper \& Row, 471 U.S. at 542-43. In Salinger, the material published without authorization dealt with an influential author whose works are typically assigned reading for high school and college students. Salinger, 811 F.2d at 92-93.

164. Harper \& Row, 471 U.S. at 553; Salinger, 811 F.2d at 99. 
preliminary sketches, and unpublished drafts of the author are critical preparatory materials for the promotion of knowledge and learning, and so at least as deserving of protection as the final materials eventually disseminated to the public. By the same token, the same kinds of materials are crucial preparation to eventual participation in public discourse and thus are at least as deserving of First Amendment protection as the speech that is finally contributed to the "marketplace of ideas." 165 Indeed, we might be far more concerned about state intervention in the private, preparatory studies and ruminations of the citizenry; such regulation would strike at the root of public discourse before it had any chance to flower. Thus, the Supreme Court has in a variety of settings declared constitutionally protected zones for private study and contemplation. ${ }^{166}$

As in the case of Navajo chants, Arnold Schoenberg's music, and Jackson Pollock's painting, ${ }^{167}$ a better candidate criterion for copyrightable expression might perhaps be the potential for the communication to be understood by another human. The picture painted in the locked room might be understood by someone besides the author if the right someone had ever seen it. However, as in the discussion of communication as a criterion for protected speech, we may learn more about the definition of copyrightable expression from observing what is not copyrightable. Quite simply, many items may be said to convey information to humans, but we do not copyright them all. For example, litmus paper conveys information about acidity to human beings, but we have not chosen to make litmus paper the subject of copyright. Litmus paper is communicative, but not expressive-at least not for purposes of copyright. Thus, communication of a message is insufficient to define copyrightable expression, although the question of communication is not irrelevant. Until the inclusion of software within copyright, we might have plausibly argued that all copyrightable subject matter had as its primary purpose the potential to communicate to humans. ${ }^{168}$ But after the decision in

165. Abrams v. United States, 250 U.S. 616, 630 (1919) (Holmes, J., dissenting) (arguing that speech should be protected because a "marketplace of ideas" will lead to the discovery of trith).

166. See, e.g., Stanley v. Georgia, 394 U.S. 555, 565 (1969) ("If the First Amendment means anything, it means that a State has no business telling a man, sitting alone in his own house, what books he may read or what films he may watch."); Sweezy v. New Hampshire, 354 U.S. 234, 250 (1957) ("The essentiality of freedom in the community of American universities is almost self-evident. . . Teachers and students must always remain free to inquire, to study and to evaluate, to gain new maturity and understanding; otherwise our civilization will stagnate and die."). Professor Cohen has argued persuasively that these precedents demarcate a constitutionally protected right both to receive information without governmental interference, and to read that information anonymously. See Cohen, supra note 92 , at $1003-19$.

167. See supra note 78.

168. Similarly, even though the primary purpose of arehitectural works is not to communicate to humans but rather to shelter them, architectural works, like software, have recently been shoehorned by Congress into the copyright category. See Judicial Improvements Act of 1990, Pub. L. No. 101650, 104 Stat. 5089, 5133 (codified at 17 U.S.C. $\S 101$ (1994)). 
Formula, such communication is no longer necessary, much less sufficient, to define eligibility for copyright. Thus, if the analogy to software copyright tells us anything at all about protecting software as speech, it suggests that the criterion of "communicativeness" fails to establish software as First Amendment subject matter anymore than it would litnius paper.

\section{Copyright and Function}

The analogy of copyrightable expression to First Amendment expression vis-á-vis software is additionally troubling when one considers the problems copyright law has had in distinguishing expression from function. The presence of software within the scope of copyright is more a matter of congressional fiat than of any logical heuristic. ${ }^{169}$ Prior to the inclusion of software as copyrightable subject matter, there was considerable controversy whether such a utilitarian work belonged under the copyright rubric. Section 102(b) of the 1976 Copyright Act states clearly that "[i]n no case does copyright protection for an original work of authorship extend to any idea, procedure, process, system, method of operation, concept, principle, or discovery." 170 This statutory section serves to exclude a variety of functional items from the scope of copyright. ${ }^{171}$ The same principle is found in the statutory protection afforded to the category of "[p]ictorial, graphic, and sculptural" works, which are protected only with regard to their artistic aspects, not their "mechanical or utilitarian aspects." 172 Similarly, since 1990 architectural works-that is, buildings and other structures-are protected under copyright, but only with regard to their creative original features, not their functional aspects or components. ${ }^{173}$

More broadly, courts generally have excluded utilitarian items fronı copyright under the principles announced by the Supreme Court in Baker $v$. Selden. ${ }^{174}$ The plaintiff in Baker sought copyright protection for printed forms that could be used to practice a method of accounting described in a book he had authored. ${ }^{175}$ But the Supreme Court reasoned that the accounting method could only be practiced by using the forms in the book, thus the forms were functional items rather than expressive

169. Cf. Julie E. Cohen, Reverse Engineering and the Rise of Electronic Vigilantism: Intellectual Property Implications of "Lock-Out" Programs, 68 S. CAL. L. REV. 1091, 1107-11 (1995) (noting the arbitrary and confusing legislative decision to classify software as copyrightable "literary works").

170. 17 U.S.C. § 102(b) (1994).

171. Including, one might logically conclude, computer software, which after all entails a process, system, or method of operation.

172. 17 U.S.C. § 101 (1994).

173. See H.R. REP. No. 101-735, at 20-21 (1990).

174. 101 U.S. 99 (1879).

175. Id. at $99-100$. 
works. ${ }^{176}$ Protecting the forms under copyright would be tantamount to protecting the method, and the protection of such items, the Court declared, was not the province of copyright, but rather of patent. ${ }^{17}$ Thus, the principle of Baker $v$. Selden infuses copyright with a broad antipathy to protection of functional objects, which includes specific codified limitations on the protection of pictorial, graphic, sculptural, and architectural works.

This distinction between functional items and expressive works has confused both courts and commentators. Professor Ginsburg, for example, argues that software is not unusual among copyrightable works by pointing to the same types of copyrightable materials the Bernstein opinion also labeled as "functional," such as maps, cookbooks, blueprints, architectural plans, and choreographic notation. ${ }^{178}$ But this comparison is, perhaps unsurprisingly, precisely the same misguided analogy between software and blueprints and the like already discussed above. ${ }^{179}$ To borrow Professor Karjala's terminology, copyrightable works such as choreographic notation or architectural plans may be "useful," but not "functional." 180 Such notation or plans might loosely be called functional in the sense that they entail instructions on how to perform a dance or construct a building. But the notes or plans are clearly separable from the works that they depict. No one would mistake choreographic notation for the dance or blueprints for a building. Cookbooks do not "configure" chefs, nor do architectural plans "configure" bricks and mortar. ${ }^{181}$ In short, such drawings or notations plainly do not behave in the sense that software does.

Despite copyright's long history of excluding functional works from the scope of its protection, in 1980 Congress followed the recommendations of the legislatively created Commission on New Technological Uses ("CONTU") 182 and placed software under the protection of the Copyright Act as a form of literary work. ${ }^{183}$ This recommendation was based partly on the concern that under existing Supreme Court precedent, patent protection would be unavailable to protect investments in the

176. Id. at 105 .

177. Id. at 104 .

178. Jane C. Ginsburg, Four Reasons and a Paradox: The Manifest Superiority of Copyright Over Sui Generis Protection of Computer Software, 94 CoLUM. L. REV. 2559, 2567 (1994).

179. See supra text accompanying notes 112-125.

180. Dennis S. Karjala, A Coherent Theory for the Copyright Protection of Computer Software and Recent Judicial Interpretations, 66 U. CIN. L. REV. 53, 57-58 (1997) (distinguishing "useful” works from "functional" works).

181. And, of course, to the extent that written instructions such as recipes are executed by a chef, that activity comprises a process outside of copyright. See, e.g., Publ'ns Int'l, Ltd. v. Meredith Corp., 88 F.3d 473 (7th Cir. 1996) (holding that unoriginal cookbook directions for combining lists of ingredients and yoghurt were uncopyrightable).

182. Congress created the Commission to study, among other things, the applicability of copyright to software. See Act of Dec. 31, 1974, Pub. L. No. 93-573, 88 Stat. 1873, 1873.

183. See Pub. L. No. 96-517, 94 Stat. 3015 (1980) (codified at 17 U.S.C. §§ 101, 117 (1994)). 
growing software industry. ${ }^{184}$ But the recommendation appears also to have been based upon a complete misconception of the nature of software by the majority of the Commissioners. ${ }^{185}$ The nature of this mistake is highlighted in the differences of analysis between the majority and dissent in the Commission's final report. The majority recommended the inclusion of software within the canon of copyright, whereas Commissioner Hersey presciently observed in dissent that software, unlike any previous form of copyrightable subject matter, does not communicate information to humans. ${ }^{186}$ Hersey quite aptly compared software to a machine part, such as a cam, noting as in the discussion of artifacts above, that mechanical artifacts may embody information of a certain sort:

A cam, like a mature computer program, is the objectification of a series of instructions: "Up, down, up, down . . ., " or "In, out, in, out ...." A cam may be the mechamical fixation of rather intricate and elegant instructions. A cam controlling a drill may embody such mstructions as: "Advance rapidly while the hole is shallow, pause and retract for a short distance to clear chips, advance more slowly as the hole goes deeper, stop at a precise point to control the depth of the hole, retract clear of the hole, dwell without motion while the work piece is ejected and another loaded; repeat procedure." (Computer programs can and do embody precisely similar instructions. $)^{187}$

But the CONTU majority was unpersuaded, retorting that "[p]rograms should no more be considered machine parts than videotapes should be considered parts of projectors or phonorecords parts of sound reproduction equipment." 188 Of course, in a very real sense, videotapes are part of projectors and phonorecords are part of sound reproduction equipment, which is precisely the reason there is a separate category of copyrightable

184. NAT'L COMM'N ON NEW TECHNOLOGICAL USES OF COPYRIGHTED WORKS (CONTU), FINAL REPORT 17 (1978) [hereinafter CONTU FINAL REPORT] (Comm'r Hersey, dissenting) (referring to Gottschalk v. Benson, 409 U.S. 63 (1972), Dann v. Johnston, 425 U.S. 219 (1976), and Parker v. Flook, 437 U.S. 584 (1978), the commission determined that "[t]he holdings of these three cases, although carefully limited in scope, make it appear that it would be difficult for any applicant to secure a patent in a prograin, since novel and useful mathematical formulas may not be patented and since useful 'post-solution applications' of them meet the same fate").

185. See Pamela Samuelson, CONTU Revisited: The Case Against Copyright Protection for Computer Programs in Machine-Readable Form, 1984 DUKE L.J. 663, 704-05.

186. CONTU FINAL REPORT, supra note 184, at 29 (Comm'r Hersey, dissenting) (arguing that "a program, once it enters a computer and is activated, does not communicate information of its own, intelligible to a human being. It utters work. . . The mature program is purely and simply a mechanical substitute for human labor.").

187. Id. at 29 (Comm'r Hersey, dissenting). Cf. Bruno Latour, The Sociology of a Few Mundane Artifacts, in SHAPING TECHNOLOGY/BUILDING SOCIETY, supra note 97, at 225-26 (noting that cars with automatic seatbelts are inscribed with the program "IF a car is moving. THEN the driver has a seat belt").

188. CONTU FINAL REPORT, supra note 184, at 21. 
embodiments called "phonorecords." Congress specifically extended copyright protection to works that must be perceived "with the aid of a machine or device" 189 because the Supreme Court in White-Smith found the piano roll to be the equivalent of a machine part. ${ }^{190} \mathrm{Be}$ that as it may, both Commissioner Hersey and subsequent commentators identified the fallacy in the CONTU majority's analogy: videotapes and phonorecords are designed to produce copyrightable output, whereas software is not necessarily or even usually designed to do so. ${ }^{191}$

Still, the observations of Professor Ginsburg and the CONTU majority at least illustrate that the problems of dealing with utilitarian works have not been entirely foreign to copyright law outside the software context. In the context of useful articles, copyright law has required separation of expression from function, and application of copyright to only the former. ${ }^{192}$ And prior to the inclusion of architectural works within copyrightable subject matter, courts drew precisely the categorical distinction suggested above between blueprints and the useful items depicted in them-the former were copyrightable, the latter were not. ${ }^{193}$ Indeed, the statutory definition of an unprotectable useful article under the copyright statute specifically excludes items whose function is "merely to portray the appearance of the article or to convey information."194 Even since December 1, 1990, when buildings embodying architectural works, as well as their drawings, became protected under copyright, the protection of such architectural works still requires discrimination between the

189. 17 U.S.C. \$ 102(a) (1994).

190. See H.R. REP. NO. 94-1476, at 52 (1976), reprinted in 1976 U.S.C.C.A.N. 5659 (amending the Copyright Act "to avoid the artificial and largely unjustifiable distinctions, derived from cases such as White-Smith Publ'g Co. v. Apollo Co.").

191. As Commissioner Hersey noted:

The functions of computer programs are fundamentally and absolutely different in nature from those of sound recordings, motion pictures, or videotapes. Recordings, films, and videotape produce for the human ear and/or eye the sounds and images that were fed into them and so are simply media for transmitting the means of expression of the writings of their authors. ... But the direct product of a computer program is a series of electronic impulses which operate a computer; the "writing" of the author is spent in the labor of the machine.

CONTU FINAL REPORT, supra note 186, at 89 (Comm'r Hersey, dissenting).

192. 17 U.S.C. \& 101 (1994); H.R. REP. No. 94-1476, at 50 (1976), reprinted in 1976 U.S.C.C.A.N. 5659.

193. See, e.g., Imperial Homes Corp. v. LaMont, 458 F.2d 895 (5th Cir. 1972) (fimding that copying of floor plans from a copyrighted brochure is infringement, but construction of a house following the brochure is not); Russell v. Trimfit Inc., 428 F. Supp. 91 (E.D. Pa. 1977), aff'd, 568 F.2d 770 (3d Cir. 1978) (holding that a registered drawing of socks conferred no rights over manufacture of the articles depicted); Jack Adelman, Inc. v. Sonners \& Gordon, Inc., 112 F. Supp. 187 (S.D.N.Y. 1934) (holding that a copyrighted drawing of a dress confers no rights over the dress itself); Combustion Eng'g, Inc. v. Murray Tube Works, 222 U.S.P.Q. (BNA) 239 (E.D. Tenn. 1984) (holding that producing parts from copyrighted technical drawings was not infringement).

194. 17 U.S.C. \& 101 (1994). Cf. supra notes 76-79 and accompanying text (noting that the function of speech is always to convey information). 
building's original design elements and those that are functionally required. ${ }^{195}$

For the purposes of the First Amendment, a similar approach for software might mean cabining source code and object code as expressive and functional, respectively. Such a rationale was advanced in the copyright arena as an argument against the copyright protection of machine-readable code. Early on, in cases such as Tandy Corp. $v$. Personal MicroComputers, Inc., ${ }^{196}$ Williams Electronics v. Artic International, Inc. ${ }^{197}$ and Apple Computer, Inc. v. Franklin Computer Corp. ${ }^{198}$ defendants charged with infringing object code argued that Congress had not intended to protect software beyond its representation as written symbols. For example, in the landmark Franklin case, a defendant charged with copying a proprietary operating system argued that the software was not protected by copyright because the program was not in written form, but rather was embedded in the silicon configuration of ROM chips. ${ }^{199}$

As might be expected from the discussion of object and source code in the previous section, this distinction was far too facile to prevail. The courts in these cases categorically rejected this line of reasoning, holding instead that programs in their machine-readable form are protected as literary works. ${ }^{200}$ From a practical perspective, this result is not surprising; the courts recognized that the conversion from source code to object code is routine, even trivial. Were object code left unprotected, infringers could easily circumvent copyright liability by reproducing and distributing code in machine-readable form. Given that Congress had declared copyright was to protect software, if that protection was to mean anything, then protection necessarily had to extend to programs in their executable form. ${ }^{201}$

195. See H.R. REP. No. 101-735, at 20-21 (1990). Thus, the expression in Robert Moses's overpasses would still probably not qualify for protection under copyright. Additionally, copyright protection of architectural works extends only to habitations, not to bridges and overpasses. See id. at 20.

196. 524 F. Supp. 171 (N.D. Cal. 1981).

197. 685 F.2d 870 (3d Cir. 1982).

198. 714 F.2d 1240 (3d Cir. 1983).

199. See id. at 1249.

200. See, e.g., id.; see also Data General Corp. v. Grumman Sys., 825 F. Supp. 340, 354-55 (D. Mass. 1993) (holding that source code and object code of an allegedly infringing program are merely two different representations of the same underlying work).

201. Apple Computer, Inc. v. Franklin Computer Corp., 714 F.2d 1240, 1249 (3rd Cir. 1983) (finding that "a computer program, whether in object code or source code . . . is protected from unauthorized copying, whether from its object or source code version"); Williams Elecs., Inc. v. Artic Int'l, Inc., 685 F.2d 870, 877 (3d Cir. 1982) (refusing to "accept defendant's suggestion that would afford an unlimited loophole by which infringement of a computer program is limited to copying of the computer program text but not to duplication of a computer program fixed on a silicon chip"); Tandy Corp. v. Personal Micro Computers, Inc., 524 F. Supp. 171, 173 (N.D. Cal. 1981) (agreeing that a computer "program fixed [on a silicon chip is] subject to the copyright laws"). 
It may have been necessary to protect particular arrangements of physical or electromagnetic media, rather than their symbolic representation, in order to effectuate congressional intent for software. Yet, these decisions did enormous violence to the coherence of copyright law as a whole. ${ }^{202}$ Since the introduction of software into copyright, courts have struggled to identify what expressive elements might exist in computer code, as software is altogether different from any previous type of copyrightable work. The distinction between function and expression has been exceedingly difficult to draw where software is concerned. ${ }^{203}$ Legal tests such as the abstraction/filtration test, designed to winnow idea from expression, have been employed to separate function from expression. In this type of infringement analysis, courts first subtract from consideration uncopyrightable elements of the works being evaluated, then they compare what remains to determine the degree of similarity between the expression contained in the works. ${ }^{204}$ But for software this exercise has been met with only mixed success, primarily demonstrating that there is little in software that is not functional. ${ }^{205}$

Consequently, far from resolving the considerable difficulties inherent in First Amendment analysis of computer code, the analogy to copyright only underscores the intractability of the function/expression dichotomy. The Bernstein trial court opimion blithely glosses over the problem that functional items, or functional aspects of creative works, are not protectable under copyright, and indeed copyright law takes some pains to distinguish the functional from the expressive, offering copyright protection only to the latter. Furthermore, if the cases and commentary on software suggest anything, it is that expression in software is thin, or perhaps nonexistent. Thus, even to the extent that expression may have similar meanings in copyright and First Amendment contexts, the copyright precedent militates away from calling software speech.

\section{Software and Patent}

I have suggested thus far that the application of the label "expression" to computer code is unwise, but not unprecedented; similarly, the comparison of expression in speech and expression in copyright is incomplete, but not inappropriate. At a minimum, the sordid history of copyright's association with software should alert us to the danger of attempting to

202. See Karjala, supra note 178 , at $92-93$.

203. Compare Whelan Assoc., Inc. v. Jaslow Dental Lab., Inc., 797 F.2d 1222, 1224-25 (3d Cir. 1986), with Computer Assocs. Int'l, Inc. v. Altai, Inc., 982 F.2d 693, 705-06 (2d Cir. 1992) (noting different standards used by courts to distinguish ideas from expression in computer programs).

204. See Nichols v. Universal Pictures Corp., 45 F.2d 119 (2d Cir. 1930) (Hand, J.).

205. See Kajjala, supra note 7, at 54 ("A court that applies the Computer Associates filters honestly will soon realize that everything in the [program sequence, structure, and organization] is present for the purpose of making the program function better, that is, for efficiency reasons."). 
shoehorn a utilitarian artifact into First Amendment categories designed with literary works in mind. But the question of protection for functional or utilitarian works is also necessarily coupled with the proprietary role of patent law. Patent law has historically compassed the protection of functional, utilitarian artifacts. ${ }^{206}$ Indeed, some commentators have viewed the division between functional and nonfunctional as the defining line between patent and copyright, ${ }^{207}$ a judgment with which the courts have tended to agree. As far back as Baker v. Selden, the Supreme Court asserted that the accounting method at issue was better the subject of patent than of copyright. ${ }^{208}$ Additionally, the patent statute specifically lists a "process" as patentable subject matter. ${ }^{209}$ More recent cases have held that the automated processes carried out by a computer-including accounting methods-may be patented. ${ }^{210}$ As a consequence, software is one of the few types of technology that is protectable not only by copyright, but also by patent.

\section{A. Patents and Function}

To say that software has been recently accommodated within patent law is not to say that software now fits comfortably within patent law. If the functional characteristics of software that fit poorly within copyright seem to indicate it would be better protected under patent law, the expressive characteristics that seem to indicate software is better protected under copyright concomitantly fit poorly within patent law. Initially, the Supreme Court seemed to indicate in Gottshalk v. Benson ${ }^{211}$ that software algorithms could not be protected under patent law. The Court reached much the same result in Parker $v$. Flook, ${ }^{212}$ but subsequently modified its rule in Diamond v. Diehr ${ }^{213}$ to hold that software could be patentable under rather stringent constraints. In particular, the Supreme Court specified that the operation of the computer program must be tied to some physical result-almost a "fixation" rule for patent law. ${ }^{214}$

206. See Reichman, supra note 7, at 2448-53.

207. See, e.g., Karjala, supra note 178 , at 56-66.

208. Baker v. Selden, 101 U.S. 99, 104, 107 (1879).

209. 35 U.S.C. $\$ 101$ (1994).

210. See AT\&T Corp. v. Excel Communications, Inc., 172 F.3d 1352 (Fed. Cir. 1999) (method for compiling a telephone record for billing purposes); St. Bank \& Trust Co. v. Signature Fin. Group, Inc., 149 F.3d 1368 (Fed. Cir. 1998) (data processing system implementing an investment method); see also Paine, Webber, Jackson \& Curtis, Inc. v. Merrill Lynch, Pierce, Fenner \& Smith, Inc., 564 F. Supp. 1358 (D. Del. 1983) (data processing method for cash management).

211. 409 U.S. 63, 71-73 (1972).

212. 437 U.S. 584,596 (1978).

213. 450 U.S. 175 (1981).

214. Id. at 191-93; cf. 17 U.S.C. $\$ \S 101,102$ (1994) (requiring that copyright subsist only in fixed works). 
This requirement of a physical result linked to the computer process was at first applied with some rigor. ${ }^{215}$ However, lower courts, particularly the Court of Appeals for the Federal Circuit, have incrementally stretched the Diehr holding to the point that patent now covers essentially any sort of software, in almost any embodiment. ${ }^{216}$ Thus, the implication of the Bernstein holding may be that we now have a category of patentable expression in computer software, a juxtaposition of legal requirements that is wholly unprecedented. Moreover, the proliferation of software-related patents for systems that traditionally constitute forms of speech, including systems of writing ${ }^{217}$ and systems for voice command recognition, ${ }^{218}$ has created a unique set of problems. Unlike copyright, which was intended to deal with expressive subject matter, patent law has been almost entirely isolated from First Amendment considerations. If copyright law has proven poorly suited to distinguishing function from expression, patent law is likely to prove even more poorly suited to the task, and may lack altogether the doctrinal tools to accommodate the First Amendment concerns associated with proprietary speech.

1. Mental Steps.-In patent, as in copyright, it has long been blackletter law that ideas are not patentable, but their physical embodiments are. ${ }^{219}$ This subject matter prohibition was in part responsible for the development of the so-called "mental steps" doctrine, which barred the patenting of mental activities. Thus, claims to a system for spacing letters written freehand were held unpatentable when the method employed only writing instruments and the human mind. ${ }^{220}$ Similarly, methods that require comparison of sounds or correlating the readings of one scale with another were held unpatentable because they depend on "correct mental

215. See, e.g., In re Schraeder, 22 F.3d 290, 293-96 (Fed. Cir. 1994) (holding a competitive bidding method unpatentable when not limited by physical elements or process steps).

216. See In re Beauregard, 53 F.3d 1583, 1584 (Fed. Cir. 1995) (dismissing an appeal when the Patent Office agreed that "computer programs embodied in a tangible medium, such as floppy diskettes, are patentable subject matter").

217. See, e.g., U.S. Patent No. 5,596,656 (issued Jan. 21, 1997) (patenting a "unistroke" system for computerized interpretation of handwriting). This particular alphabetic system has been the subject of protracted litigation. See Xerox Suit Against 3Com over "Graffiti" Moves Forward, CNETNEwS.COM (Jan. 10, 2000), at http://news.cnet.com/news/0-1006-200-1519369.html.

218. See, e.g., U.S. Patent No. 6,073,097 (issued June 6, 2000) (patenting an invention that will "provide apparatuses and methods for increasing the ease, convenience, and accuracy with which a user of a word recognition system, such as speech recognition system, can train that system to understand his words").

219. Gottschalk v. Benson, 409 U.S. 63, 69 (1972) ("It is conceded that one inay not patent an idea."); $c f .17$ U.S.C. $\S 102(\mathrm{~h})$ (1994) ("In no case does copyright protection . . . extend to any idea ....").

220. Ex parte Meinhardt, 1907 Dec. Comm'r Pat. 237; see also DONALD S. CHISUM, CHISUM ON PATENTS $\S 1.03[6]$, at 1-78.9 to 1-79 (2000) (summarizing Ex parte Meinhardt). 
comparisons"221 and "purely[ mental act[s]."222 Patentable methods could not be dependent. on the intelligence of the person operating the device ${ }^{223}$ but rather must recite "true mampulative steps." 224 This requirement evolved into a doctrine that if the novel or nonobvious feature in a process consisted of mental steps, the process was unpatentable; but if the novelty or nonobviousness lay in physical steps to which mental steps were incidental or essential to limit the claim scope, then the process would be patentable. ${ }^{225}$

Almost as soon as it was formulated, however, this doctrine began to erode. The imitial fault lines appeared around the question of whether processes that could either be performed mentally or mechanically could be patentable under the doctrine. Considering a mathematical process step that could, at least theoretically, have been performed with just pencil and paper, the Court of Custom and Patent Appeals held that patentability was not precluded for processes capable of mechanical implementation simply because the process could alternatively be carried out by mental steps. ${ }^{226}$ Imitially, process claims that were broad enough to cover mental steps were held to encompass nonstatutory subject matter, but were permissible if limited to implementation by machines. Subsequently, such broad process claims were held not to encompass unpatentable subject matter, but merely to raise problems of claim definiteness. Claims encompassing mental steps involving "aesthetic, emotional, imaginative, or creative thought or reactions on the part of the practitioners" could be held indefinite, but claims drawn to any process that could be implemented by machine would be sufficiently definite. ${ }^{227}$

This holding cleared the way for claims directed to computer implementation of process steps and set the stage for the evolution of software patentability. The subsequent history of the mental steps doctrine itself was shaped by the Supreme Court's Benson/Flook/Diehr trilogy of cases, which addressed the patentability of computer-implemented mathematical algorithms. Much of the discussion in these cases is directed to

221. Johnson v. Dusquesne Light Co., 29 F.2d 784, 786 (W.D. Pa. 1928) (observing that the efficacy of the device at issue depended upon the operator's ability to compare two sounds).

222. Ex parte Read, 123 U.S.P.Q. (BNA) 446, 447 (Pat. Off. Bd. App. 1943) (noting that the "act of correlating the reading of one scale with reading on the other" is unpatentable).

223. See Johnson, 29 F.2d at 786 (holding unpatentable a method that required "the intelligence" of the operator to be "brought into play" in order to yield results).

224. Ex parte Read, 123 U.S.P.Q. (BNA) at 447.

225. In re Abrams, 89 U.S.P.Q. (BNA) 266, 268-69 (C.C.P.A. 1951); see also In re Heritage, 66 U.S.P.Q. (BNA) 217, 220 (C.C.P.A. 1945) ("Such purely mental acts are not proper subject matter for protection under the patent statutes ....").

226. In re Prater, 415 F.2d 1393, 1405 (C.C.P.A. 1969).

227. In re Musgrave, 431 F. $2 \mathrm{~d} 882,890$ (C.C.P.A. 1970). 
the statutory subject matter question of whether algorithms constitute unpatentable ideas or laws of nature. ${ }^{228}$ The mental steps doctrine was largely lost in the shuffle, although in Benson, the Supreme Court appears to have concurred with the mental steps argument against software patentability. ${ }^{229}$ The Court stated that along with phenomena of nature and abstract intellectual concepts, "mental processes . . . are not patentable, as they are the basic tools of scientific and technological work." 230 At the same time, the Court's focus on the patentability of "algorithms"231 shifted the development of software patent doctrine to an entirely new theory and away from the mental steps argument, making Benson essentially the last word on the subject. ${ }^{232}$ The Federal Circuit subsequently defined "mathematical algorithm" to include any mental process that can be represented by a mathematical algorithm and then declared mathematical algorithms patentable so long as they produce some "useful, concrete, and tangible result."233

As a consequence, courts had little difficulty in tying software to a physical substrate. To constitute patentable subject matter, the software needed simply to produce some physical change in a machine, which the steps of a software algorithm unquestionably do; the execution of each step in a computer program places the hardware in a different electrical or magnetic state. ${ }^{234}$ Thus, stored data in a computer memory may be patentable, since the storage of the data places the machine in a different state than it would otherwise have been. ${ }^{235}$ Storing data or computer code on a magnetic disk may similarly be considered to produce a novel and nonobvious article of manufacture, since the magnetic disk with the stored data differs from the disk without it. ${ }^{236}$ Consequently, "it is of

228. See Pamela Samuelson, Benson Revisited: The Case Against Patent Protection for Algorithms and Other Computer Program-Related Inventions, 39 EMORY L.J. 1025, 1028 n.3 (1990).

229. Gottschalk v. Benson, 409 U.S. 63 (1972).

230. Id. at 67.

231. See id. at 65 .

232. See Samuelson, supra note 228 , at 1061-62.

233. In re Alappat, 33 F.3d 1526, 1544 (Fed. Cir. 1994) (en banc).

234. See, e.g., id. at 1545 (stating that the court has held that loading software "creates a new machine, because a general purpose computer in effect becomes a special purpose computer once it is programmed to perform particular functions pursuant to instructions from program software" (citations omitted)). In fact, although the Federal Circuit continues to pay some lip service to the requirement of a tangible substrate, it appears from recent cases that the court believes a numerical manipulation need only achieve a "useful result." AT\&T Corp. v. Excel Communications, Inc., 172 F.3d 1352, 1360 (Fed. Cir. 1999); see also id. at 1358 (asserting that "physical transformation" is not an invariable requirement for patentability).

235. In re Lowry, 32 F.3d 1579, 1583 (Fed. Cir. 1994).

236. See In re Beauregard, 53 F.3d 1583, 1584 (Fed. Cir. 1995) (dismissing an appeal as moot after the Patent Office acquiesced to the submission of an encoded computer disk as statutory subject matter). 
little relevance whether [a software] claim . . . is directed to a 'machine' or a 'process," ${ }^{237}$ since under this view the process produces a series of different machines.

But such interpretive legerdemain ignores the issue undergirding the mental steps doctrine: that conferring a broad property right in cognitive process steps appropriates publicly necessary information to private use. This objection may be implicit in the Supreme Court's comment in Benson that mental processes cannot be patentable because they are the "basic tools of scientific and technological work." 238 There may be a number of explanations as to why the basic tools of research should not be subject to proprietary claims, but implicit in the Court's comment is the recognition that permitting an exclusive right in mental steps would curtail freedom of inquiry. Although courts have merely flatly declared that "[i]t is selfevident that thought is not patentable," 239 some commentators have noted the social disutility likely to arise from patenting basic algorithms that can be performed as mental steps. ${ }^{240}$ At a minimum, enforcing such claims would be troublesome. As a more serious matter, there would seem to be profound First Amendment implications to the concept of infringement by "thinking patented thoughts."241

A similar argument has previously arisen in litigation over the mental steps doctrine. In rejecting a patent for a method for selecting the optimal set of equations for certain spectrographic analyses, the Patent Office argued that claims drawn to mental processes would preclude people from thinking in certain ways or create the possibility of mentally infringing claims. ${ }^{242}$ The appellate court failed to address this argument directly, although it did quote the assertion from an amicus brief that "purely mental activity would not be infringement since there would be no harm to the patentee, an essential element for any tort." ${ }^{243}$ This assertion is somewhat difficult to follow given that unauthorized making, use, or sale of a process falling within the scope of valid patent claims is by definition infringement of the patent. ${ }^{244}$

237. State St. Bank \& Trust Co. v. Signature Fin. Group, Inc., 149 F.3d 1368, 1372 (Fed. Cir. 1998).

238. Gottschalk v. Benson, 409 U.S. 63,67 (1972).

239. See, e.g., In re Abrams, 89 U.S.P.Q. (BNA) 266, 269 (C.C.P.A. 1951).

240. See, e.g., Allen Newell, Response: The Models are Broken, The Models are Brokenl, $47 \mathrm{U}$. PITT. L. REV. 1023 (1986).

241. Id. at 1025.

242. In re Prater, 415 F.2d 1378, 1391-92 (C.C.P.A. 1968) (Rich, J., dissenting from grant of rehearing).

243. In re Prater, 415 F.2d 1393, 1400 n.20 (C.C.P.A. 1969).

244. See 35 U.S.C. \& 271(a) (1994 \& Supp. IV 1998) (stating that "whoever without authority makes, uses, offers to sell, or sells any patented invention, within the United States or imports into the United States any patented information during the term of the patent therefor, infringes the patent"). 
Addressing claims that might encompass either human or mechanical implementation, the same court later indirectly dismissed the First Amendment concern, stating that it knew of "no authority for holding that a human being, such as a draftsman, could ever be the equivalent of a machine disclosed in a patent application," 245 which suggests a unique status for human thought processes as unparalleled by mechanical data processing. ${ }^{246}$ From a philosophical perspective, the human mind may or may not be the equivalent of a digital computer. ${ }^{247}$ But, from a patent law perspective it is difficult to point to any authority that would preclude such a holding of computational equivalency where a claim was drafted in broad language. ${ }^{248}$ Broad application of the claims would not require a holding that the human mind is a digital computer, or even like a digital computer-only that the mental process was a means for performing the same function, which it clearly could be. As a consequence, expressive processes encompassed by human cognition now appear to be encompassed within the patent statute. The prospect that cognitive processes could be subject to current patent law does not bode well for the future of expressive freedom in the patent arena.

2. Printed Matter.-A second patentability restriction-also in decline with the expansion of software patents, but with even clearer implications for speech-is the printed matter doctrine. U.S. courts have long held that mere arrangement of lines or symbols does not constitute patentable subject matter as such markings would not be within patentable subject matter as a new and useful machine, manufacture, or composition of matter. ${ }^{249}$ Thus, forms and labels whose sole patentable characteristic derived from

245. In re Bernhart, 417 F.2d 1395, 1399 (C.C.P.A. 1969).

246. Cf. Searle, supra note 78, at $418-19$ (declaring that machines are incapable of human understanding).

247. See id.

248. Certainly in other areas it seems clear that humans may be swept into the scope of such broad claims-for example, where the patentability of living organisms is at issue, the Patent Office expressly requires that the claims of the patent be drawn to nonhuman subject matter. See Commissioner of Patents and Trademarks, Policy Statement on Patentability of Animals, 1077 Off. Gaz. Pat. Office 24 (Apr. 21, 1987). The Patent Office argues that such a limitation is required by the anti-slavery provisions of the Thirteenth Amendment. See id. In the case of computational processes, ownership issues would perhaps not be raised by inclusion of humans as an element of the process claim, rather than as the subject of a product claim-a patent presumably confers no ownership to an element of a claim, as opposed to the subject matter of the claim. Even in the latter case, however, I have argued that there is no element of ownership implicated by the Thirteenth Amendment. See Dan L. Burk, Patenting Transgenic Human Embryos: A Nonuse Cost Perspective, 30 Hous. L. REv. 1597, 1648-49 (1993).

249. In re Russell, 48 F. $2 \mathrm{~d} 668,669$ (C.C.P.A. 1931) ("The mere arrangement of printed matter on a sheet or sheets of paper . . . does not constitute 'any new and useful art, machine, manufacture, or composition of matter" ...."). 
such indicia have been held unpatentable. ${ }^{250}$ In particular, differences in substance, language, or meaning of printed indicia are not patentable. ${ }^{251}$ This is not to say that an invention is not patentable simply because it is printed on paper or some other substrate. Rather, the rule is that in order to meet the criteria for patentability, claims must define new features of physical structure or new relations of printed matter to structure. ${ }^{252}$

As a consequence of this limitation, courts long held that accounting or indexing methods that involved novel arrangements of symbols on known substrates-such as paper-were unpatentable. ${ }^{253}$ Similarly, methods of arranging directory names by phonetic groups have been held unpatentable in situations where the patentable characteristics lay in the arrangement of the names. ${ }^{254}$ Perhaps quite by happenstance, this line of cases reinforced the dictum of Baker $v$. Selden ${ }^{2 s 5}$ that drew the dividing line between copyright and patent: literary works were categorically excluded from patentability as printed matter. Ironically, the uncopy-rightable accounting forms of Baker $v$. Selden would also have likely been unpatentable as printed matter. ${ }^{256}$ So, too, the uncopyrightable directory of Feist ${ }^{257}$ would likely have been denied a place among patentable subject matter as an unpatentable collection of names, numbers, and addresses. ${ }^{258}$

Indeed, one corollary of the printed matter prohibition was that business methods, such as the accounting method of Baker $v$. Selden, would generally fail patentability criteria for want of a physical

250. See generally 1 CHISUM ON PATENTS, supra note 220, $\$ 1.02$ [4] (summarizing the holdings of several cases applying the printed matter doctrine).

251. Ex Parte Gwinn, 112 U.S.P.Q. 439, 446-48 (Pat. Off. Bd. App. 1955).

252. See, e.g., Flood v. Coe, 31 F. Supp. 348, 349 (D.D.C. 1940) (holding that the claimed invention was patentable because its "unique relationship between the physical structure and the printed matter" represent "more than an arrangement of printed matter on a piece of paper").

253. See, e.g., Guthrie v. Curlett, 10 F.2d 725, 726 (2d Cir. 1926) (holding that an index of railroad tariffs was not patentable).

254. In re Russell, 48 F.2d 668 (C.C.P.A. 1931).

255. 101 U.S. 99, 102 (1879) ("To give to the author of the book an exclusive property in the art described therein, when no examination of its novelty has ever been officially made, would be a surprise and a fraud upon the public. That is the province of letters-patent, not of copyright.").

256. See In re Lowry, 32 F.3d 1579, 1582 (Fed. Cir. 1994) (refusing to "give patentable weight to printed matter absent a new and unobvious functional relationship between the printed matter and the substrate"); United States Credit Sys. Co. v. Am. Credit Indem. Co., 59 F. 139, 143 (2d Cir. 1893) ("There is nothing peculiar or novel in preparing a sheet of paper with headings generally appropriate to classes of facts to be recorded .... Given a series of transactions, there is no patentable novelty in recording them ....").

257. Feist Publ'ns, Inc. v. Rural Tel. Serv. Co., 499 U.S. 340 (1991).

258. See Guthrie, 10 F.2d 726-27 (2d Cir. 1926) ("In this case . . . no means are suggested for making a consolidated index, except the employment of symbols .... [T] he only possibly novel part [of the invention] ... can be copyrighted, but not patented .... [A]dvice as to how to compile [an index] . . . is not patentable." (emphasis added)). 
substrate. 259 By contrast, some methods of fraud prevention involving detachable menu or railway tickets were held patentable because they were tied to a physical cardboard ticket structure involved in the process. ${ }^{260}$ The requirement of a physical substrate for printed matter evolved into the Diehr requirement that software must be tied to a tangible embodiment to qualify as patentable subject matter, where the printed matter cases intersected with the mental steps cases. Professor Chisum notes that the two doctrines are closely related, as a claim including printed or symbolic elements will tend to require human evaluation or interpretation and so invoke the mental steps analysis discussed above. ${ }^{261}$ Indeed, the Federal Circuit appears to have equated the two lines of cases in one recent decision, characterizing the printed matter cases as those dealing with claims to "novel arrangements of printed lines or characters useful and intelligible only to the human mind."262

Such a patentability doctrine directed to arrangements of symbols has clear implications for the patentability of computer programs. As was inevitable, the printed matter doctrine first fully encountered the digital age and all its corollary issues of communication, function, and expression. In Application of Jones, ${ }^{263}$ the court considered the patentability of an encoder disc with a pattern of transparent and opaque areas; light flashed through the disc and was read out by photocells on the other side. The patentee claimed a new pattern on the disc that corrected for errors in the accuracy of the disc. ${ }^{264}$ The court held that this new pattern was not merely an arrangement of printed matter, largely because it constituted "functional elements of a mechanism which in use actuate other mechanisms or electrical circuits or devices"265 and involved no "'printing' ... in the form of words or other symbols intended to convey intelligence to a reader . . ." "266 But as we have seen in the prior discussion, such distinctions between functional patterns and those intended to "convey meaning" are increasingly blurred; one dissenting judge in Jones noted, "I

259. See, e.g., Rand, McNally \& Co. v. Exchange Scrip-Book Co., 187 F. 984, 986 (7th Cir. 1911) (distinguishing an unpatentable business method from a patentable "tangible facility" that is used in a business method).

260. See, e.g., Cincinnati Traction Co. v. Pope, 210 F. 443 (6th Cir. 1913) (nuling a street car transfer ticket was patentable); Rand, McNally \& Co. v. Exchange Scrip-Book Co., 187 F. 984 (7th Cir. 1911) (holding a detachable coupon ticket patentable); Benjamin Menu Card Co. v. Rand, McNally \& Co., 210 F. 285 (N.D. Ill. 1894) (finding a detachable menu-meal ticket patentable).

261. 1 CHISUM ON PATENTS, supra note 220 , § 1.02[4], at 1-28.2.

262. In re Lowry, 32 F.3d 1579, 1583 (Fed. Cir. 1994) (quoting In re Bernhart, 417 F.2d 1395, 1399 (C.C.P.A. 1969)).

263. 373 F.2d 1007 (C.C.P.A. 1967).

264. Id. at 1011-12.

265. Id. at 1013.

266. Id. 
have difficulty in distinguishing the subject matter said to be patentable from the arrangements of numbers on the dial of an ordinary bathroom scale." 267

The Jones holding thus presages the recent software patent cases in which the Federal Circuit has held that claims involving digitized information are distinguishable from printed matter. The court's reasoning has been that digitized information involves no "arrangements of printed lines or characters useful and intelligible only to the human mind," but rather involves "specific electrical or magnetic structural elements" processed by a machine. ${ }^{268}$ As such, claims drawn to such computer programs are drawn to "a new machine" that is "physically different from the machine without that program; its memory elements are differently arranged." 269 These holdings fit hand in glove with recent opinions rejecting the mental steps doctrine as a bar to software patentability, including cases affirming the patentability of digitally implemented business methods. ${ }^{270}$

Thus, under current caselaw holding all manner of business methods patentable, the phonetic arrangement of names would now be presumably patentable if accomplished digitally. Similarly, under the "new machine" doctrine, arrangements of data within a computer memory have been held to create a novel, potentially patentable, item. ${ }^{271}$ One wonders if, under current patent caselaw, the telephone book of Feist loaded into computer memory might now be patentably novel, if not copyrightably original. Additionally, all copyrightable subject matter now seems to be patentable so long as it is digitized. This potential for patenting creative works was recognized by the dissent in a recent case holding software patentable as the configuration of a new machine:

Consider for example the discovery or creation of music, a new song. Music of course is not patentable subject matter; a composer cannot obtain exclusive patent rights for the original creation of a musical composition. But now suppose the new melody is recorded on a compact disc. In such case, the particular musical composition will define an arrangement of minute pits in the surface of the compact disc material, and therefore will define its specific structure.

267. Id. at 1015 (Kirkpatrick, J., dissenting).

268. In re Lowry, 32 F.3d 1579, 1583-84 (Fed. Cir. 1994).

269. Id. at 1583 (quoting In re Bernhart, 417 F.2d 1395, 1399 (C.C.P.A. 1969)).

270. See, e.g., AT\&T Corp. v. Excel Communications, Inc., 172 F.3d 1352, 1358-59 (Fed. Cir. 1999); State St. Bank \& Trust Co. v. Signature Fin. Group, Inc., 149 F.3d 1368, 1373-77 (Fed. Cir. 1998).

271. State St. Bank \& Trust Co., 149 F.3d at 1373-77; accord In re Warmerdam, 33 F.3d 1354, 1361 (Fed. Cir. 1994) (reversing the Board of Patent Appeals's decision that a machine's data structure was "indefinite," but expressing no opinion as to the structure's patentability). 
... Alternatively suppose the music is recorded on the rolls of a player piano or music box. . . . [I]f a claim to a compact disc or piano roll containing a newly discovered song were regarded as a "manufacture" and within $\S 101$ simply because of the specific physical structure of the compact disc, the "practical effect" would be the granting of a patent for a discovery in music. ${ }^{272}$

This is, of course, the logical endpoint of treating not only software, but any digitized information, as entirely functional and entirely equivalent to Commissioner Hersey's cam: the embodiment of the information becomes in essence a densely programmed artifact. To fit software within copyright, function must be treated as if it were expression; to fit software within patent law, the converse holds true. In treating digitized information as "specific magnetic structural elements" processed by a machine, ${ }^{273}$ current patent subject matter doctrine ignores or subliminates the "printed lines or characters, useful and intelligible only to the human mind" that are essential to treating software as a literary work under copyright. ${ }^{274}$ Patent law thus sweeps within its ambit everything from $\mathrm{DNA}^{275}$ to piano rolls, and potentially any encoded expression that such objects may carry along with them.

\section{B. Patents and Expression}

One response to the looming dilemma of patentable expression might be to avoid the entire problem by somehow isolating the functional portions

272. In re Alappat, 33 F.3d 1526, 1553-54 (Fed. Cir. 1994) (Archer, J., dissenting) (citation omitted). Note that the Patent Office has attempted to forestall Judge Archer's prediction by instructing its examiners to reject claims drawn to "non-functional descriptive material," which "includes but is not limited to music, literary works, and a compilation or mere arrangements of data," while allowing claims drawn to "functional descriptive material" which "consists of data structures and computer programs which impart functionality when encoded on a computer-readable medium." PATENT AND

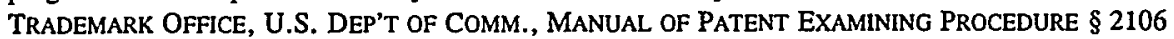
(7th ed. 1998). Such instructions optimistically assume that an examiner can differentiate between dcscriptive material that is functional and material that is nonfunctional and are besides incompatible with Federal Circuit caselaw on the subject. See, e.g., In re Warmerdam, 33 F.3d 1360-61 (approving claims drawn to "a machine having a memory which contains data . . . generated by" an unpatentable algorithm).

273. In re Lowry, 32 F.3d at 1583-84.

274. Id. at 1583 (quoting In re Bemhart, 417 F.2d 1395, 1399 (C.C.P.A. 1969)).

275. One common complaint regarding recent Federal Circuit biotechnology opinions dealing with DNA patentability, such as In re Bell, 991 F.2d 781 (Fed. Cir. 1993), and In re Deuel, 51 F.3d 1552 (Fed. Cir. 1995), is that the court treats DNA solely as a cog in the biological machine, rather than as an informational program. See Arti K. Rai, Intellectual Property Rights in Biotechnology: Addressing New Technology, 34 WAKE FOREST L. REV. 827, 833-38 (1999) (criticizing this approach to biotechnology patents); Anita Varma \& David Abraham, DNA is Different: Legal Obviousness and the Balance Between Biotech Inventors and the Market, 9 HARV. J.L. \& TECH. 53, 65-78 (1996) (same). One wonders whether such commentators truly wish for the Federal Circuit to apply its standards for informational inventions, as described here, to biomolecules. 
of software from the expressive portions, and applying patent law to only the former. This is the approach implicit in the Bernstein panel's holding that the First Amendment reaches expressive aspects of functional works and is essentially the agenda that has been followed in copyright by attempting to separate the expressive from the unexpressive through means of abstraction and filtration. But this past history suggests that the prospects for such an agenda in patent law are not cheery: the abject failure of both courts and commentators to effectively accomplish such a separation for purposes of copyright does not bode well for the success of a similar project within patent. As shown by the previous discussion of embedded values, ${ }^{276}$ expression in its broad sense is an inherent characteristic of human artifacts, including technological artifacts. If one insists, as I have argued that the Bernstein and Junger opinions insist, that expression in its broad sense constitutes protected speech, then it may be difficult to find any utilitarian object that is not somehow expressive.

Moreover, patent law as presently constituted is devoid of any analog to-or what would be better, any improvement upon-the abstraction/filtration test, which has been employed to try to separate function from expression in copyright. Unlike copyrights, whose scope is generally determined ex post by judicial review, ${ }^{277}$ the scope of patents is fashioned ex ante by administrative review of applications in the Patent Office. ${ }^{278}$ To be certain, the language of a given patent grant may be interpreted in an infringement action by a court. But the language of that grant, in the form of claims, is hammered out before issuance in an iterative process of negotiation between the patentee and a patent examiner. ${ }^{279}$ Unpatentable subject matter within the claims should have been identified and eliminated during the examination process. And where it has not been, judicial review in a subsequent challenge is exercised not to determine what bits within the scope of the claims are patentable or unpatentable, but rather whether the patent is valid as a whole.

Of course, as with the interpretation of any legal text, a court engaging in the interpretation of patent claims has some degree of latitude in including or excluding certain subject matter within the scope of the

276. See supra text accompanying notes 93-99.

277. See Apple Computer, Inc. v. Microsoft Corp., 35 F.3d 1435, 1443 (9th Cir. 1994) (noting that "[a]lthough this litigation has raised difficult and interesting issues about the scope of copyright protection ...., resolving this appeal is a matter of applying well-settled principles"); Brown Bag Software v. Symantec Corp., 960 F.2d 1465, 1472 (9th Cir. 1992) (explaining that "[s]ummary judgment for a defendant accused of copyright infringement is appropriate when the plaintiff fails to show a genuine issue regarding whether the ideas and expressive elements of the works are substantially similar" (citing Frybarger v. Int'l Bus. Machs. Corp., 812 F.2d 525, 528 (9th Cir. 1987))).

278. 35 U.S.C. $\$ 131$ (1994 \& Supp. I 2000).

279. Id. § 132 . 
right. ${ }^{280}$ In theory, this interpretive power might be exercised ex post to exclude troublesome expressive aspects of software from protection. But this approach speaks only to the mechanism by which expression might be segregated, not the criteria for doing so. No particular doctrine of claim interpretation is directed toward determining what might or might not be expressive, so one would have to be fashioned from whole cloth. Additionally, although courts in patent cases have some degree of latitude in claims interpretation, claims are not to be treated "like a nose of wax which may be turned and twisted in any direction." 281 At some point, claims interpretation will be cabined by the description of the invention, the prosecution history, and the language of the claim itself. ${ }^{282}$ That limit likely falls well short of the license necessary to expunge unpatentable expression.

A variant on the "separation" solution is suggested in a recent article by Professors Lemley and Volokh on copyright injunctions in which they briefly note the potential for patentable expression under Bernstein. ${ }^{283}$ Lemley and Volokh attempt to reconcile this problem by invoking the distinction between source code and object code, arguing that patent law should treat executable software as a virtual machine, while treating source code as protected expression. ${ }^{284}$ Under this analysis, the functional object code would receive full patent protection, and the expressive source code would not. ${ }^{285}$ But this artificial distinction is specious at best, and more likely mischievous. As discussed above, in the case of uncompiled coding languages, such as Perl, the distinction between functional code and written code completely collapses. ${ }^{286}$ Moreover, even if we consider only compiled programs, the analysis from parallel copyright cases indicates that this distinction is unlikely to be helpful. From Apple Computer, Inc. v. Franklin Computer Corp. ${ }^{287}$ on, copyright law has rejected this distinction with good reason: if only source code is considered protected expression, infringers could evade copyright law by instead trading in unauthorized object code. Under the legal regime that

280. See, e.g., Autogiro Co. of Am. v. United States, 384 F.2d 391, 396 (Ct. Cl. 1967) ("Although courts are confined by the language of the claims, they are not, however, confined to the language of the claims in interpreting their meaning.").

281. White v. Dunbar, 119 U.S. 47,51 (1886).

282. See Autogiro, 384 F.2d at $396-98$.

283. Lemley \& Volokh, supra note 137 , at 236.

284. Id. at 236-37. This suggestion was seized upon by the trial court in Reimerdes in an attempt to distinguish function from expression in the DeCSS decryption.program. See Universal City Studios, Inc. v. Reimerdes, 82 F. Supp. 2d 211, 219 n.30, 222 n.48, 226 n.75 (S.D.N.Y. 2000) (citing the Lemley and Volokh analysis of the source code/object code relationship).

285. Lemley \& Volokh, supra note 137, at 236.

286. See supra note 111 and accompanying text.

287. 714 F.2d 1240 (3d Cir. 1983). 
Professors Lemley and Volokh advocate, patent infringers might evade patent law-or at least patent injunctions-by doing the opposite: trading in unauthorized source code, which would be unprotected, in order to circumvent the patent protection of object code.

The Lemley and Volokh argument suggests that such circumvention might not matter much because a patent includes the exclusive right to use the claimed invention. The patent on the program would, at least in theory, prohibit use of the machine-readable version of the source code. Indeed, such prohibited uses might include compiling of the source code. ${ }^{288}$ But, policing prohibited uses of patented inventions is notoriously difficult. For precisely this reason it is a maxim-and almost a cliché-that a patent owner would rather hold a product patent than a process patent. This situation has been particularly apparent in the chemical and biotechnological arts, where an inventor may hold the patent on a particular chemical or biological process, but may not concurrently hold the patent on the materials either produced by or used in the process. ${ }^{289}$ If the materials are proprietary, then their appearance in the marketplace signals infringement. But process infringement occurs behind the scenes, in use or production of the unpatented materials, and it is not always possible to tell whether the materials were made via the patented process or via some other public domain process. If, in fact, use of object code were the measure of software patent protection, software patenting would be forced into the same difficulties of detection and enforcement that have plagued biotechnology. ${ }^{290}$

Alternatively, it is unclear whether distribution of source code might constitute infringement by equivalents of an object code invention. The patent law doctrine of equivalents penalizes devices or activities that may not fall within the literal scope of a patent's claims, but which are known

288. See Julie E. Cohen \& Mark A. Lemley, Patent Scope and Invention in the Software Industry 89 CALIF. L. REV. (forthcoming January 2001).

289. See DAVID SCHWARTZMAN, INNOVATION IN THE PHARMACEUTICAL INDUSTRY 167 (1976) (noting that patents covering chemical composition of the active ingredient are more significant than process patents because of the difficulty of enforcing a process patent).

290. These problems are particularly serious when the use occurs offshore. See generally U.S. INT'L TRADE COMM'N, FOREIGN PROTECTION OF INTELLECTUAL PROPERTY RIGHTS AND THE EFFECT ON U.S. TRADE (1988). Offshore uses are to some extent addressed by the addition of $\$ 271(\mathrm{~g})$ to the patent statute. See 35 U.S.C. $\$ 271$ (g) (1994) (prohibiting importation, offers of sale, or use of a product made by a process patented in the United States). However, because this statute was aimed at tangible products, especially chemicals, it is unclear how it would apply in the context of patented computer processes. See, e.g., Dan L. Burk, Patents in Cyberspace: Territoriality and Infringement on Global Computer Networks, 68 TULANE L. REV. 1, 45-47 (1993) (discussing the possible application of existing laws to "the electronic importation of data products derived from an infringing software process"). 
substitutes for the claimed invention ${ }^{291}$ or perform substantially the same function as the claimed invention, yielding the same results via substantially the same means. ${ }^{292}$ Source code is surely a known substitute for object code and lacks only the step of compilation-if that-to perform the same functions in the same way with the same result. Of course, under the Lemley/Volokh bifurcation, source code is to be treated as a text, and it may be that a writing cannot constitute the equivalent of a functional invention. But given the wholesale collapse of the mental steps and printed matter doctrines, textual instructions might constitute an equivalent. The question remains both unsettling and unsettled.

One might also reasonably presume that no one would distribute compilable source code unless it was intended to be compiled into object code: programs, as observed above, are valued exclusively for their behavior. Thus, the distributor of source code should almost certainly know that infringing compilation will inevitably follow from source code distribution. But this reasoning raises other serious problems in the current structure of patent law. For example, one might argue that distributing source code accompanied by instructions on how to execute it could constitute inducement to infringe. The patent statute not only prohibits direct acts of infringement, but also indirectly "aiding and abetting" infringement. ${ }^{293}$ Courts have long held that distribution of unpatented items together with instructions on how to use them to infringe a patented process constitutes inducement ${ }^{294}$-one is reminded of the common practice in some programming languages of interspersing executable statements with nonexecutable comments, thereby concatenating instructions with the means to infringe object code. Humans typically do not follow source code instructions to arrange voltages in computational registers.

Alternatively, distribution of "expressive" source code could constitute separately actionable contributory infringement under 35 U.S.C. § 271(c). The analysis under this portion of the patent statute depends heavily upon whether the unpatented items in question are staple articles of commerce susceptible to a variety of uses or nonstaple articles that are especially

291. See Wamer-Jenkinson v. Hilton-Davis Chem. Co., 520 U.S. 17, 35 (1997).

292. See id. at 1051-53 (discussing with favor, but declining to decide, that something performing a similar function via similar means infringes a patent). See Insituform Tech., Inc. v. Cat Contracting Inc., 161 F.3d 688, 692 (Fed. Cir. 1998) (upholding the district court's finding of infringement because the claimed process included "substantially the same function, way and result").

293. 35 U.S.C. \$ 271(b) (1994 \& Supp. IV 1998) ("Whoever actively induces infringement of a patent shall be liable as an infringer.").

294. See, e.g., Dawson Chem. Co. v. Rohm \& Haas Co., 448 U.S. 176, 187-99 (1980) (holding that defendants induced infringement by instructing farmers how to apply an unpatented herbicide to their crops); $c f$. United States v. Bamett, 667 F.2d 835 (9th Cir. 1982) (holding that supplying instructions directing manufacture of contraband drugs can constitute criminal aiding and abetting). 
adapted to be used in the patented process and which would have no substantial noninfringing use. ${ }^{295}$ As compared to patented object code, it is difficult to characterize complementary source code as anything but a nonstaple article-it is clearly specially adapted to be used with the patented object code and essentially lacks a noninfringing use. Note that this situation stands in stark contrast to that in copyright, where a noninfringing or fair use would include decompilation of object code. ${ }^{296}$ In patent law, there is no doctrine of fair use, and every use of a patented item is presumptively infringing.

Yet Lemley and Volokh suggest that contributory infringement prohibitions against distributing instructions may themselves be unacceptable prior restraints on speech. ${ }^{297}$ If this is indeed the case, then the patentee would as a practical matter be unable to enjoin distribution of source code either as a direct patent infringement or as a contributory infringement. Thus, under any of these lines of analysis, attempting to cabin source code as expression seems to be an exercise in futility. Current patent doctrine would quickly render any distinction between object code and source impractical: the two forms are too closely tied not to be treated as a proprietary package, and protecting either as functional will inevitably entangle the expressive analog with the proprietary right.

\section{Patents and Speech}

If digitized expression is to be covered by patent law and cannot be readily expunged from patent coverage, then it seems inevitable that patent law must now confront the free speech issues attending expressive subject matter. This, in turn, suggests that some form of fair use may be necessary in patent law, like in copyright, where the Supreme Court has suggested that it is necessary to accommodate First Amendment concerns. ${ }^{298}$ The suggestion of patent fair use is not entirely new, ${ }^{299}$ but no such doctrine exists in patent law at present. To the extent that fair use is required to accommodate freedom of expression, it may be that

295. See 35 U.S.C. § 271(c) (1994 \& Supp. IV 1998).

296. See Sega Enters. Ltd. v. Accolade, Inc., 977 F.2d 1510, 1527-28 (9th Cir. 1992); see generally Cohen, supra note 167 , at 1100 ( $[$ [D]ecompilation of computer object code is a fair use privileged by the Act when there is no other way to gain access to the functional requirements for interoperability, which are not protected by copyright.").

297. See Lemley \& Volokh, supra note 135, at 169.

298. See Harper \& Row, Publishers, Inc. v. Nation Enters., 471 U.S. 539, 556 (1985); see also RODNEY A. SMOLLA, SMOLLA AND NIMMER ON FREEDOM OF SPEECH \$ 21:11-12, at 21-43 (1996).

299. See Donald S. Chisum, The Patentability of Algorithms, 47 U. PITT. L. REV. 959, 1018 (1986) (arguing for a right of fair use in patent law); see also Maureen A. O'Rourke, Toward $a$ Doctrine of Fair Use in Patent Law, 100 COLUM. L. REV. 1177, 1180 (2000) (arguing that patent fair use is needed to address market failures). 
patent law has never before needed such a doctrine. Yet, given the variety of functions for fair use within copyright, the absence of some analog in patent law is curious and deserves an explanation, if one is possible.

1. The Function of Fair Use.-In the copyright arena, fair use has been explained as a legal accommodation to "market failure" in licensing copyrighted works. ${ }^{300}$ On this theory of market failure, fair use exists to facilitate worthwhile employment of copyrighted works in which the value of the use is exceeded by the transaction costs of negotiating a license. Under such conditions, an unfettered right to exclude might deter such valuable uses because the potential user of the work is unlikely to expend more to locate the owner and negotiate a license than he can recover from the licensed use. The fair use doctrine allows the potential user to take the needed portion of the work and make use of it without seeking a license, bypassing the need for deterrent high-cost authorization.

But the unadorned market failure theory by itself cannot explain or justify much of the jurisprudence of fair use under conditions of normal transaction cost, to unauthorized uses of relatively minor value, or to unauthorized uses of more substantial uses only where the transaction costs were exceptionally high. Yet the Supreme Court has made it clear that unauthorized use of a work may be fair even when the copyright owner can be easily located and licensing mechanisms are available. For example, in Campbell v. Acuff-Rose, ${ }^{301}$ the rap music group 2 Live Crew's unauthorized parody of a copyrighted song was held to fall within fair use, even though they had previously contacted the song's copyright owner, requested a license, and been refused. ${ }^{302}$ Additionally, the 2 Live Crew parody was marketed for profit, suggesting that the value of the use to the group was not exceeded by the transaction costs of licensing-indeed quite the opposite value differential may have been the case. ${ }^{303}$

The 2 Live Crew case is emblematic of a second type of fair use market failure, occurring in circumstances where copyrighted works have socially valuable uses, but that value is not fully internalized. ${ }^{304}$ Commentary, criticism, parody, and other unauthorized uses may be of significant value in encouraging public debate and fostering an informed populace, but this value is diffuse and accrues to recipients other than the

300. Wendy J. Gordon, Fair Use as Market Failure: A Structural and Economic Analysis of the Betamax Case and its Predecessors, 82 COLUM. L. REV. 1600, 1601 (1982).

301. 510 U.S. 569 (1994).

302. Id. at 594 .

303. Id. at 573.

304. See Robert P. Merges, Are You Making Fun of Me?: Notes on Market Failure and the Parody Defense in Copyright, 21 AIPLA Q.J. 305 (1993). 
user of the copyrighted work. ${ }^{305}$ In the case where such positive externalities are present, social welfare would be increased by the use of the work, but the potential user may be deterred from doing so because he will not assess the use at full value. Only a portion of the value of the new work will accrue to the potential user, and transaction costs in excess of that portion will produce the market failure described above. ${ }^{306}$ In order to encourage creation of the work, fair use may again serve to bypass licensing that appears excessively costly from the perspective of the potential user. Because of the subject matter of copyright, instances of such positive externality may tend to track the social purposes of the First Amendment; broader dissemination of literary, artistic, and similar works will tend to directly or indirectly sustain social dialogue and public debate. Thus, fair use may accommodate free speech interests directly, providing the content for such exchanges, and indirectly by fostering, an aware and educated populace better able to participate in the exchange.

One would assume that in the case of functional technology, no less than in the case of nonfunctional expressive works, instances might arise where market failure of the copyright fair use variety is present. ${ }^{307}$ The cost of locating a patent owner and negotiating a license might well deter a potential user from engaging in valuable social use of the claimed invention. The second type of fair use market failure may also be present vis-a-vis functional technologies: certain uses may entail positive externalities, where the social value of certain uses of patented technology may be too diffuse to prompt a potential user to seek a license. In the case of functional technologies, such positive externalities may not necessarily entail the promotion of public discourse, as in the case of copyrighted

305. See Lydia Pallas Loren, Redefining the Market Failure Approach to Fair Use in an Era of Copyright Permission Systems, 5 J. INTELL. PROP. L. 1, 49-50 (1997) (arguing that market failure exists when external societal benefits from unauthorized use cannot be internalized). Professor Yen has argued that society may also have "non-economic" interests in the production of such uses. See Alfred C. Yen, When Authors Won't Sell: Parody, Fair Use, and Efficiency in Copyright Law, 62 U. COLO. L. REV. 79, 89-94 (1991). Such interests may, well exist, but many if not all of the interests he identifies are likely subsumed in the economic description considered here.

306. This problem reaches its zenith in situations of review or parody that might damage the market for the underlying work: society has a strong interest in the commentary or the burlesque, but the production of such a derivative work is directly contrary to the interests of the owner of the criticized material. See Richard A. Posner, When is Parody Fair Use?, 21 J. LEGAL STUD. 67, 71-72 (1992) (suggesting limitations on the application of the fair use doctrine to parodies).

307. See Robert P. Merges, Intellectual Property Rights and Bargaining Breakdown: The Case of Blocking Patents, 62 TENN. L. REV. 75, 78-84 (1994) (detailing reasons for patent licensing market failures). Merges proposes that judicial intervention via the reverse doctrine of equivalents, which excuses otherwise literal infringement of patent claims, ameliorates some of these failures. Id. at 9195. However, Professor Lemley has shown that reverse equivalents are not the patent equivalent of fair use. See Mark A. Lemley, The Economics of Improvement in Intellectual Property, 75 TEXAS L. REV. 989, 1024-26 (1997). 
works. Yet there may be socially beneficial technological advances or improvements on patented technology that might fall into this category.

Despite these factors, the conventional wisdom has long been that patent owners must be free to exercise the right to exclude potential users in precisely the manner that was not permitted to the copyright holder in Campbell v. Acuff-Rose. ${ }^{308}$ The precise reason for such a broad right is unclear, if indeed there is any reason. The standard explanation for the breadth of the patent right is that development of functional technology is much more capital intensive than creative works subject to copyright; therefore, as an incentive to development, society must offer a right that allows the maximum return on investment. ${ }^{309}$ One might question whether the assumption that copyrighted works are relatively cheap to produce continues to hold true: counterexamples might include software development or even the production of a special-effects intensive motion picture. ${ }^{310}$ Indeed, one argument in favor of expanding copyright protection, or restricting fair use, is that a broader right is necessary to induce creation of technology-intensive creative works. But if the cost of creating such works has expanded so far, then the distinction between patent and copyright seems difficult to explain on the basis of cost differences.

An alternative explanation for patents, which has begun to be applied to copyrights, is the so-called prospect theory advanced by Edmund Kitch. ${ }^{311}$ Kitch argues that, as in the case of development of real property, development of technology is best placed in the hands of a single private owner. ${ }^{312}$ This owner then has a profit incentive to allocate the property-either real or intellectual-to its most valuable use. ${ }^{313}$ Under this theory, it is especially important for the private owner to have maximum control over the property so as to better coordinate its development because uncoordinated development of the property or

308. See Roger D. Blair \& Thomas F. Cotter, An Economic Analysis of Seller and User Liability in Intellectual Property Law, 68 U. CIN. L. REv. 1, 12 (1999) (comparing copyright and patent law and noting that unlike copyright law, patent law "prohibits all unauthorized uses of patented inventions" and does not provide liberal exceptions to liability).

309. See O'Rourke, supra note 295 , at $1196 \mathrm{n} .78$ (discussing the reasons for the difference between copyright and patent law incentive structures).

310. See, e.g., Josb Chetwynd, Lights, camera, money? Financiers play growing role in movie making, U.S.A. TODAY, March 8, 1999, at 1B(lamenting the fact that major motion pictures often cost more than $\$ 100$ million), available at http://pqasb.pqarchiver.com/USAToday/.

311. Edmund W. Kitcb, The Nature and Function of the Patent System, 20 J.L. \& ECON. 265 (1977).

312. Id. at 266 (arguing that like the development of real property, the development of technological innovations requires scarce resources, and having only one developer promotes efficiency by eliminating wasted developmental resources).

313. Id. at $276-77$ ("[T] patent owner has an incentive to make investments to maximize the value of the patent without fear that the fruits of the investment will produce unpatentable information appropriable by competitors."): 
technology may result in conflicting, incompatible uses. Presumably, loopholes such as patent fair use would tend to impede the patent owner's ability to control the technology's use, and so lead to uncoordinated development.

But if the market failure theory of fair use is accepted, these arguments make little sense for either creative or functional works, under either a theory of incentive or coordination. The point of the market failure theory is that the license would never have been taken anyway, so when incentive justifications are considered, there is no loss of revenue to the intellectual property owner. Restricting fair use, or having no fair use at all, simply deprives society of a benefit without increasing the returns to the rights holder. In market failure of the first type, the coordinator of the intellectual property will have no opportunity to consider the use to which the fair user would put the property since the user will never ask for a license. And in positive externality market failure, the coordinator would fail to consider the social benefit of the use, as it would not accrue to him. Thus, neither of these theories provides any substantial insight into why fair use should not apply to both copyrights and patents.

It is worth noting that some functions of fair use may be served by the doctrine of blocking patents, which Professor Lemley has recently observed occur in patent law but not in copyright. ${ }^{314}$ Those who improve patented technology are entitled to a patent on the improvement if it meets the statutory criteria. Lemley has argued that this situation in essence creates a divided property right, which may encourage bargaining between the owners of the two halves. ${ }^{315}$ I have argued elsewhere that fair use may produce some divided entitlement effect. ${ }^{316}$ Yet not all improvements to patented technology are themselves patentable, in which case the improver may be left without the bargaining leverage of a divided property right. For that matter, even blocking patents do not excuse unauthorized uses, as would fair use. Thus, it is not clear that the public interest function fulfilled by fair use would be served by blocking patents as neither party would be likely to internalize the public benefits of the use. Some other doctrine is needed to play the role of solving market failure in patents.

2. Experimental Use.-Perhaps the closest that current patent law approaches to a doctrine resembling fair use is the judicially created doctrine of experimental use, which therefore becomes a prime candidate

314. Lemley, supra note 304, at 992.

315. Id. at 1062.

316. See Dan L. Burk, Muddy Rules for Cyberspace, 21 CARDozo L. REV. 121, 144 (1999) (arguing that fair use in copyright may facilitate divided property bargaining); see also Lemley, supra note 307, at 1024 (noting that fair use protects improvers under some circumstances). 
to play the role of fair use in the brave new world of patentable expression. Under this doctrine, otherwise infringing use of a claimed invention may be excused when engaged in for experimental purposes. The doctrine has its origins in the famous nineteenth century dictum by Justice Story in Whittemore v. Cutter ${ }^{317}$ that "[i]t could never have been the intention of the legislature to punish a man, who constructed such a machine merely for philosophical experiments, or for the purpose of ascertaining the sufficiency of the machine to produce its described effects." 318

Story's rationale in Whittemore appears to have rested in part upon the need to assemble and test a claimed invention in order to determine whether the disclosure in the patent specification was enabling. Reasoning that the essence of the patent bargain is disclosure in return for exclusive rights, Story suggested that review by the government might be insufficient to detect defective or nonenabling disclosure, and so private testing of the claimed invention might be implicitly authorized. ${ }^{319}$ In particular, under the 1793 patent statute considered, patent filings were reviewed by the attorney general for legal sufficiency, unlike the current practice of review by an administrative agency staffed by examiners with expertise in the technology. Given the procedure at the time of Whittemore, ex post testing by private entrepreneurs may have been the only feasible review of the disclosure.

Thus, the experimental use exception appears to have some roots in the public interest in ferreting out inoperable patents and in public access to technology that should properly have been in the public doniain. But Story's exception was also clearly influenced by the minimal harm to the patentee arising from noncommercial usage. In Whittemore, Story was opining on the propriety of a jury instruction that limited infringement to "the making of a machine fit for use, and with a design to use it for profit." 320 Later in the same year, Story again formulated his conception of experimental use in such terms:

[T] he making of a patented machine to be an offence ... must be the making with an intent to use for profit, and not for the mere purpose of philosophical experiment, or to ascertain the verity and exactness of the specification. In other words, that the making must be with an intent to infringe the patent-right, and deprive the owner of the lawful rewards of his discovery. ${ }^{321}$

317. 29 F. Cas. 1120 (C.C.D. Mass. 1813).

318. Id. at 1121 .

319. Id. at 1122 .

320. Id. at 1121 .

321. Sawin v. Guild, 21 F. Cas. 554, 555 (C.C.D. Mass. 1813) (citations omitted). 
Subsequent courts seized upon the criteria of commerciality, making it the centerpiece of their experimental use analysis, and holding, for example, that a jury instruction of the kind considered in Whittemore-that use of a patented invention "merely for experiment, and not with a view to profit"-was a proper formulation of the test. ${ }^{32}$ But the concept of commercial use for these purposes became extremely broad. The 1890 Robinson patent treatise framed the question in terms of uses "hostile to the interest of the patentee" as "represented by the emoluments which he does or might receive from the practice of the invention by himself or others." ${ }^{323}$ Thus, experimental use was confined to those activities that did no harm to the pecumary interests of the patent holder.

Consequently, almost any connection with a commercial enterprise has been found sufficient to negate experimental use. The defense has been rejected for use of the claimed invention to determine its suitability for a particular business purpose, ${ }^{324}$ to improve the claimed invention, ${ }^{325}$ to develop alternative technology, ${ }^{326}$ to compare it to alternative technologies, ${ }^{327}$ or even simply to see if the claimed invention worked. ${ }^{328}$ In this vein, perhaps the best known failure of the experimental use defense has been in the area of pharmaceutical manufacture, where the Federal Circuit held the defense did not excuse infringing activity related to a generic drug manufacturer's preparations for production of a pharmaceutical in anticipation of the expiration of the pharmaceutical patent. The court in Roche v. Bolar ${ }^{329}$ correctly characterized the exception as "truly narrow" and limited to experiments conducted "for amusement, to satisfy idle curiosity, or for strictly philosophical inquiry." 330 Because the activity or clinical testing in Roche was related to a commercial purpose, even a future noninfringing commercial purpose, it was not an experimental use.

In response to the Federal Circuit's Roche holding, Congress created one of the few statutory exceptions to a patentee's exclusive right. Under this statutory amendment, a generic manufacturer can begin to obtain Federal Drug Administration approval for a patented drug during the life of the patent without liability for infringement. ${ }^{331}$ The statutory

322. See, e.g., Byam v. Bullard, 4 F. Cas. 934, 935 (C.C.D. Mass. 1852).

323. William C. ROBINSON, THE LAW OF PATENTS AND USEFUL INVENTIONS $\S 898$ (1890).

324. See Spray Refrigeration Co. v. Spray Fishing Inc., 322 F.2d 34, 36-37 (9th Cir. 1963).

325. See Cimiotti Unhairing Co. v. Derboklow, 87 F. 997 , 999 (C.C.E.D.N.Y. 1898).

326. See PairPearl Prods., Inc. v. Joseph H. Meyer Bros., 58 F.2d 802, 804-05 (D. Me. 1932).

327. See RCA v. Andrea, 15 F. Supp. 685, 687 (E.D.N.Y. 1936).

328. See Nat'l Meter Co. v. Thomson Meter Co., 106 F. 531, $541-42$ (C.C.S.D.N.Y. 1900).

329. 733 F.2d 858 (Fed. Cir. 1984).

330. Id. at 863.

331. 35 U.S.C. § 271(e)(1) (1994 \& Supp. IV 1998). 
exemption applies solely to development of information that must be submitted in order to obtain permission to sell the drug. ${ }^{332}$ Significantly, the enactment of this amendment was driven in large measure by the public interest in access to the patented technology: if competitors to the patentee could not be ready to enter the market at the expiration of the patent term, the significant lag time necessary to gain regulatory production and marketing approval would effectively extend the period of patent protection. ${ }^{333}$ Thus, the statutory exception incorporates at least some of Justice Story's original rationale for the experimental use exception.

Nonetheless, the congressional creation of the pharmaceutical exemption was not the creation of a blanket experimental use exemption, and the judicially created exemption remains inapplicable to the majority of cases. In rare instances, the courts have permitted it to excuse otherwise infringing activity where the sole purpose of the activity was to determine the operability of a claimed invention. ${ }^{334}$ Experimental use has also been sparingly applied in a university setting where the activity was deemed purely academic, in both senses of the word. ${ }^{335}$ This latter application of the doctrine has served as the scenario for arguing the importance of experimental use. One commentator has suggested that development of a robust and updated experimental use doctrine may be necessary to allow socially valuable uses of patented technology in scientific inquiry. ${ }^{336}$ Despite this renewed interest in the experimental use exception, Roche and subsequent cases suggest that there is little enthusiasm in the courts for a renaissance of experimental use. Congress similarly bypassed the opportunity to draft a broad statutory experimental use exception, hewing instead to a narrowly drawn response to Roche.

This doctrine could at best serve as a basis for patent fair use, not as a substitute. It incorporates only one-and at best two-of the factors found in the current statutory formulation of copyright fair use. ${ }^{337}$ Significantly, it lacks criteria related to public benefit-the criterion most necessary to accommodating First Amendment interests. In Justice Story's

332. Id.

333. See H.R. REP. NO. 98-857, pt. 2, at 29-30 (1984), reprinted in 1984 U.S.C.C.A.N. 2647, 2713-14 (arguing the amendment did not allow for takings prohibited by the Fifth Amendment).

334. See, e.g., Dugan v. Lear Avia, Inc., 55 F. Supp. 223, 229 (S.D.N.Y. 1944); Akro Agate Co. v. Master Marble Co., 18 F. Supp. 305, 333 (N.D. W. Va. 1937).

335. See Ruth v. Stearns-Roger Mfg. Co., 13 F. Supp. 697 (D. Colo. 1935) (refusing to award damages for unauthorized sales of a patented machine to a university for "experimental purposes" that "does not contribute to an infringing use").

336. See Rebecca S. Eisenberg, Patents and the Progress of Science: Exclusive Rights and Experimental Use, 56 U. CHI. L. REV. 1017 (1989).

337. 17 U.S.C. $\S 107(1)$ (1994) (recognizing both "the purpose and character of the use" as factors to be considered in determining whether a use of a copyrighted work is fair use). 
original formulation of the doctrine, there seems to be consideration of the public benefit in the unauthorized use. But this factor is tenuous, and was subsequently all but blotted out in consideration of the potential for harm to the market for the intellectual property. The obsession with this consideration has almost negated any other consideration that might enter into the applicability of the doctrine. Ironically, recent copyright decisions indicate that analysis of copyright fair use may be heading in the same direction. Several influential copyright opinions have evaluated fair use primarily on whether the use harmed the market for the licensing of the material used. ${ }^{338}$ As the dissent in one copyright case noted, this approach will always yield a finding of infringement because fees that the copyright holder might extract from the market will be "lost" if the taking were deemed fair use. ${ }^{339}$ One is reminded of the long line of patent cases referenced above holding that a use was commercial, and thus not experimental, because of the "emoluments" the patentee would lose were the use deemed experimental. Thus, if fair use and experimental use are converging, it is not because patent law is beginning to accommodate public access to expression, but rather because copyright is beginning to fail in doing so. We must look elsewhere for a doctrine to accommodate public access.

3. Compulsory Licensing.-An alternative approach to establishing patent fair use might be to look to forms of compulsory licensing. Both fair use and experimental use might be characterized as a type of compulsory license at a royalty of zero; given this characterization, a doctrine that facilitates compulsory licensing of patents might be adapted to serve the same function as fair use. But unlike the U.S. Copyright Act, which is positively lousy with compulsory licenses, ${ }^{340}$ statutory permission to infringe is almost unknown to the Patent Act. The few examples of compulsory licenses that do exist tend to be encroachments from other areas of regulation. For example, under the Atomic Energy Act, a compulsory licensing scheme exists for inventions related to civilian uses of fissile material..$^{34}$ The Nuclear Regulatory Commission ("NRC") is empowered to permit applicants to use such an invention on equitable terms if the NRC finds the invention to be fundamental to civilian

338. See, e.g., Princeton Univ. Press v. Michigan Document Servs., Inc., 99 F.3d 1381 (6th Cir. 1996); Am. Geophysical Union v. Texaco, Inc., 60 F.3d 913 (2d Cir. 1994).

339. Princeton Univ. Press, 99 F.3d at 1407 (Ryan, J., dissenting).

340. See, e.g., 17 U.S.C. \$§ 11 (d) (1994) (compulsory license for cable transmission), 115(a) (1994 \& Supp. IV 1998) (compulsory license for sound recordings), 119 (1994 \& Supp. 1V 1998) (compulsory license for satellite retransmission), 118 (1994) (compulsory license for public television). 341. 42 U.S.C. § 2183 (1994 \& Supp. IV 1998). 
nuclear power production. Such a finding is in essence a requirement to negotiate, and if the patent holder and potential users fail to agree on equitable terms, the NRC can set a reasonable royalty rate for the license. A similar system exists under a seldom-invoked provision of the Clean Air Act for technology that is essentially mandated under the Act: the patent holder is first required to attempt negotiation of reasonable terms, and if such negotiation fails, a rate is set by the government. ${ }^{342}$ Congress also recently created a novel statutory exception to the patent holder's exclusive right by precluding enforcement of patents for medical procedures against health professionals who use the process without authorization. ${ }^{343}$ This last exception provides for no remuneration to the patentee and, like fair use in copyright, essentially allows a compulsory license at a zero royalty.

Compulsory licensing with or without remuneration also appears occasionally as an infringement remedy, or perhaps as the lack of an infringement remedy. In some cases, courts have denied injunctive relief on grounds of public need for access to the technology claimed in an infringed patent. ${ }^{344}$ However, these cases are not concerned with access to patented inventions as a matter of general social policy. The public interest recognized in these cases is specific and varies widely; for example, medical need, public sanitation, or transportation disruptions may occasion the denial of an injunction. ${ }^{345}$ This variance may reflect the nature of the relief sought in these cases. Courts dispensing preliminary relief are charged with weighing the potential harm to the plaintiff and the strength of the plaintiff's case against the potential harm to the defendant and the public interest. ${ }^{346}$ The equitable balancing involved in preliminary relief may raise the issue of public interest more squarely than it might be in other instances. ${ }^{347}$

The surprising feature of these cases is the court's willingness to second-guess the public interest analysis already performed by the legislature. Where patent infringement is concerned, the calculus of public

342. Id. § 7608(1) (1994).

343. 35 U.S.C. \& 287(c) (Supp. IV 1998).

344. See, e.g., Nerney v. New York, 83 F.2d 409 (2d Cir. 1936); City of Milwaukee v. Activated Sludge, Inc., 69 F.2d 577 (7th Cir. 1934).

345. See Nerney, 83 F.2d at 411 (refusing to grant an injunction because doing so would cause transportation disnuptions to the public); City of Milwaukee, 69 F.2d at 593 (refusing to grant an injunction when doing so would force the city to dump its sewage into Lake Michigan); Hybritech Inc. v. Abbott Lab., 4 U.S.P.Q.2d (BNA) 1001, 1015 (C.D. Cal. 1987) (refusing to grant an injunction when doing so would limit public access to test kits for caucer and hepatitis).

346. See John Leubsdorf, The Standard for Preliminary Injunctions, 91 HARV. L. REV. 525, 54042 (1978); see also Am. Hosp. Supply Corp. v. Hosp. Prod. Ltd., 780 F.2d 589, 593 (7th Cir. 1986) (balancing preliminary relief factors in an algebraic equation); supra note 345.

347. See Laura Stein, The Court and the Community: Why Non-Party Interests Should Count in Preliminary Injunction Actions, 16 REV. LITIG. 27, 29 (1997) ("Many courts interpret the public interest factor as a license to consider the impact that granting or denying injunctive relief will have on non-parties ...."). 
interest is generally relatively straightforward in favor of an injunction, on the assumption that the relief is required by the patentee's right to exclude $^{348}$ Patents are generally conceived of as a property right, ${ }^{349}$ which almost by definition entails the right to exclude. ${ }^{350}$ The denial of injunctive relief effectively turns the patent from a property rule into a liability rule; that is, from a right to exclude into a right to receive damages. In some instances, courts denying the injunction have explicitly recognized this by awarding damages at a reasonable royalty to create a compulsory license. ${ }^{351}$ But since such a remedy is generally contrary to the majority of patent decisions, and arguably contrary to patent policy, courts are likely to create such a compulsory license only in unusual circumstances. "Fair use" of patentable expression might constitute such an unusual circumstance and indeed, long before its codification, copyright fair use first evolved by just such a common law approach. But there may be considerable judicial inertia to overcome in reaching such a result, even though such an expansion of compulsory licensing seems to be just what patent law needs to cope with the addition of expressive subject matter to its scope of protection.

\section{Conclusion}

If patent law is unable to separate the expressive and functional aspects of computer code, then it may instead be required to somehow accommodate First Amendment interests in that code, much as copyright law has done in its development of fair use, original authorship, and the idea/expression dichotomy. But patent law at present is singularly illequipped to make such an accommodation, particularly now that it has been reshaped to protect computer algorithms. It is no coincidence that the admission of software into the canon of patentable subject matter has resulted in the systematic eradication of a cluster of patent doctrines, for it was precisely these doctrines restricting the patentability of mental steps

348. See Smith Int'l, Inc. v. Hughes Tool Co., 718 F.2d 1573, 1581 (Fed. Cir. 1983).

349. See 35 U.S.C. $\$ 261$ (1994) (stating that "subject to the provisions of this title, patents shall have the attributes of personal property").

350. See Smith Int'l, 718 F.2d at 1581 ("The very nature of the patent right is the right to exclude others."); see also Panduit Corp. v. Stahlin Bros. Fibre Works, Inc., 575 F.2d 1152, 1158 n.5 (6th Cir. 1978) (asserting that "[t]he right to exclude others is the essence of the human right called "property" ). This is in fact the classic definition of a property rule. See RICHARD POSNER, ECONOMIC ANALYSIS OF LAW 10-15 (4th ed. 1992) (claiming that exclusivity is an essential element of any efficient system of property rights); Guido Calabresi \& A. Douglas Melamed, Property Rules, Liability Rules, and Inalienability: One View of the Cathedral, 85 HARV. L. REV. 1089, 1092 (1972) ("An entitlement is protected by a property rule to the extent that someone who wishes to remove the entitlement from its holder must buy it from him in a voluntary transaction in which the value of the entitlement is agreed upon by the seller.").

351. See, e.g., Foster v. Am. Mach. \& Foundry Co., 492 F.2d 1317, 1324 (2d Cir. 1974). 
or printed matter that tended to impede the incorporation of software into patentable subject matter. The introduction of expressive subject matter into patent law may require revival or reformation of one or more of these patent doctrines in order to re-establish the line between function and expression in patentable subject matter. Alternatively, some doctrine of patent fair use may be required to accommodate expressive material that falls under the patent umbrella.

This leads to two brief concluding observations drawn from the theme of function and expression that runs throughout the law surveyed above. First, although much of the inquiry in this Article has been given over to the insights into patent law that may be gleaned from parallel copyright and First Amendment jurisprudence on expression, it may be that the experience of intellectual property law may inform future free speech analysis. Given the parallels that I have discussed in this Article and the troubled history of software in patent and copyright law, I fear much the same fate for our First Amendment jurisprudence. The problem of function versus expression, reflected in the reasoning of the copyright software cases, may now be essentially imported into First Amendment jurisprudence together with all inherent tensions and inconsistencies that it entails. We risk repeating all the worst mistakes of the last twenty years of copyright software cases in future decisions concerning free speech.

Or, perhaps not-warned by our previous experience in intellectual property, perhaps it is possible to chart a more sane course for the law of First Amendment. If software has been a hybrid that blurs the distinction between function and expression in intellectual property, it may similarly blur the distinction between artifact and expression in the area of speech. By anticipating such a hybrid, perhaps we can better deal with it. Probably the most sensible suggestion that has been made for intellectual property protection of hybrids is that because they do not fit neatly into the old categories that encompassed, respectively, functional works and expressive works, they require their own novel brand of intellectual property protection. ${ }^{352}$ The same may be true of hybrids in the context of the First Amendment-comprising neither protectable speech nor utilitarian function, they may require their own category of protection. This would not be an unusual move in the law of free speech, having been done in the past with commercial speech ${ }^{353}$ and with expressive conduct. ${ }^{354}$

And finally, to the extent that digitized information may introduce the problem of expressive subject matter into patent law, the lack of existing

352. See Peter Menell, Tailoring Legal Protection for Computer Software, 39 STAN. L. REV. 1329 (1987); Samuelson, supra note 185, at 663.

353. See LAWRENCE H. TRIBE, AMERICAN CONSTITUTIONAL LAW § 12-5, at 890-904 (2d ed. 1988).

354. See id. § $12-3$, at $794-804, \S 12-7$, at $825-32$. 
patent doctrine to address this problem may not prove disastrous. It is conceivable that the opportunity to write such doctrines on a blank slate may be something of a blessing in disguise. Much of the confusion in the area of software copyright arises out of the attempt to apply previously existing doctrines to a subject matter for which they were never intended. In patent law, perhaps new doctrines can be tailored specifically to the problem of patenting speech. 